\title{
The Effect of Prices on Nutrition: Comparing the Impact of Product- and Nutrient-Specific Taxes*
}

\author{
Matthew Harding ${ }^{\dagger} \quad$ Michael Lovenheim ${ }^{\ddagger}$
}

February 27, 2017

\begin{abstract}
This paper provides an analysis of the role of prices in determining food purchases and nutrition using very detailed transaction-level observations for a large, nationallyrepresentative sample of US consumers over the period 2002-2007. Using productspecific nutritional information, we develop a new method of partitioning the product space into relevant nutritional clusters that define a set of nutritionally-bundled goods, which parsimoniously characterize consumer choice sets. We then estimate a large utility-derived demand system over this joint product-nutrient space that allows us to calculate price and expenditure elasticities. Using our structural demand estimates, we simulate the role of product taxes on soda, sugar-sweetened beverages, packaged meals, and snacks, and nutrient taxes on fat, salt, and sugar. We find that a $20 \%$ nutrient tax has a significantly larger impact on nutrition than an equivalent product tax, due to the fact that these are broader-based taxes. However, the costs of these taxes in terms of consumer utility is only about 70 cents per household per day. A sugar tax in particular is a powerful tool to induce healthier nutritive bundles among consumers.
\end{abstract}

KEYWORDS: food and nutrient demand, SSBs, food taxes, purchasing environments, QUAIDS

JEL CLASSIFICATION: I12, I19, C33

${ }^{*}$ Research support from the Robert Wood Johnson Foundation, the UPS Foundation, and the U.S. Department of Agriculture is gratefully acknowledged. Binying Liu provided excellent research assistance. We thank Jerry Hausman, Ephraim Leibtag, Arthur Lewbel, Aviv Nevo, and conference participants at the AEA Annual Meetings, the 2013 RWJ Healthy Eating Conference, and the 9th Conference on Industrial Organization and the Food Processing Industry, Toulouse, June 21-22, 2012 for excellent comments. Any opinions, findings, recommendations, or conclusions are those of the authors and do not necessarily reflect the views of the Economic Research Service, U.S. Department of Agriculture.

$\dagger$ Department of Economics and Department of Statistics, University of California - Irvine, 3207 Social Science Plaza B, Irvine, CA 92697; Phone: (949) 824-1511; Email: harding1@uci.edu

${ }^{\ddagger}$ Department of Policy Analysis and Management, College of Human Ecology, Cornell University, 102 Martha Van Rensselaer Hall, Ithaca, NY 14853 and NBER; Phone: (607)255-0705; Fax: (607)255-4071; Email: mf155@cornell.edu

Page 1 of 45

(C) 2017. This manuscript version is made available under the Elsevier user license http://www.elsevier.com/open-access/userlicense/1.0/ 


\section{Introduction}

Obesity is one of the largest prevailing public health concerns in the United States. National obesity rates (defined as having a body mass index (BMI) greater than $30 \mathrm{~kg} / \mathrm{m}^{2}$ ) have increased dramatically among both children and adults over the past several decades. In the late 1970s, the national obesity rate among adults was about $14.5 \%$; it increased to $22.5 \%$ by the early 1990s (Flegal et al., 1998). Today, over 2/3 of Americans are overweight and over $36 \%$ are obese. $^{1}$ Estimates also suggest that about $30 \%$ of children are obese or overweight, although the trend appears to have flattened somewhat in recent years (Ogden et al., 2010; Cawley, 2010). Obesity has been linked to a higher prevalence of chronic diseases, such as arthritis, diabetes and cardiovascular disease (Must et al., 1999; Pi-Suyner, 1991). The associated cost to the U.S. medical system has been estimated to be between $\$ 147$ billion and $\$ 210$ billion per year, with Medicare and Medicaid financing approximately half such costs (Finkelstein et al., 1998; Levi et al., 2014). The high and rising obesity rate combined with the financial burden it places on the health care system have made it one of the leading public health problems in the United States.

The rise in obesity can be ascribed mainly to the fact that physical exercise has not increased over this time period but calories consumed have grown dramatically (Cutler et al., 2003). The implication is that Americans are consuming an increasingly unhealthy diet, both in terms of the total number as well as the composition of calories. With over $2 / 3$ of household caloric intake occurring at home (Nestle, 2012), a question of central importance is why households are purchasing large quantities of more unhealthy food and what public policies could be used to support purchasing a more healthy nutritional bundle. The core type of policies that have been discussed in the economics and public health communities are price-based interventions, such as a sugar-sweetened beverage (SSB) tax or a fat tax. To date, however, there is little robust evidence on how price policies will affect the products consumers purchase and the resulting nutritional bundles of households. While these types of food taxes have long been considered politically infeasible, they have now been introduced in many countries around the world and in many states and localities in America.

The lack of understanding of how price-based policies will affect nutrition is surprising given the pervasive policy discussions throughout the world on how to use the tax system to support healthier eating. However, there are several data limitations and methodological complications

\footnotetext{
${ }^{1}$ The Economist. Special Report: Obesity. December 15, 2012.
} 
prior work has faced that has limited our understanding of price-based nutritional policies. In this paper, we combine structural demand techniques with extremely detailed data that provide a comprehensive view of consumer purchases, prices, nutritional characteristics of foods purchased, and purchasing environments. Our analysis focuses on identifying the role of prices in driving the type and nutritional content of foods households purchase for home consumption. We thus shed needed light on how consumption bundles and nutrition are shaped by the prices consumers face in order to inform the development of appropriate price-based policies to support nutritional goals policymakers may have. The size and scope of our data allow us to partition the product space into "nutritional clusters" that represent distinct sets of product types within each product group (e.g., diet and regular soda, sliced bread and pastries, candy and cookies). We then estimate a structural Quadratic Almost Ideal Demand System (QUAIDS) model over the joint product-nutrient groups at the household-month level, accounting for the endogeneity of prices with instruments based on marginal cost variation and the endogeneity of expenditures using instruments based on local business cycle variation. Using the resulting price and expenditure elasticities, we simulate the effect of various product (e.g., soda) and nutrient (e.g., sugar) taxes on the distribution of consumer expenditures across groups and on the distribution of nutrients. We also calculate the consumer welfare costs of each tax.

Our main finding from the tax simulations is that nutrient-specific taxes have much larger effects on nutrition than do product-specific taxes, without causing a larger decline in consumer utility. The intuition for this result is that nutrient-based taxes have a much broader base, so it is more difficult to substitute away from any one good in response to such taxes. For example, a $20 \%$ tax on soda decreases total purchased calories by $4.84 \%$ and decreases sugar consumption by over $10 \%$. However, a $20 \%$ sugar tax decreases total calories by over $18 \%$ and sugar by over $16 \%$. The larger effect of a sugar tax on nutrition comes despite the fact that it has the same effect on indirect utility as a soda tax. Due to their negative income elasticities and the patterns of own- and cross-price elasticities we find, taxes on snacks and packaged meals have very small effects on nutrition. Fat and salt taxes, on the other hand, have much larger effects, decreasing calories by $19 \%$ and $11 \%$, respectively. SSB taxes, which can be thought of as a hybrid price policy that targets a set of products based on their nutritional content, also are quite effective, reducing caloric intake by over $8 \%$. However, these taxes are less-effective and only slightly lessdistortive than a broad-based sugar tax. Overall, our results point to large potential impacts of nutrient-based taxes on nutrition that are driven by their broad base. Among these, sugar taxes stand out as being particularly effective at supporting healthier purchasing behavior. 
This paper makes several contributions to our understanding of how price-based interventions affect nutrition. First, a major limitation that prior research has faced is the lack of comprehensive data linking consumer purchases to prices and nutrition. The dataset we assemble for this project is unique in its size and scope: no prior work has used data that has the volume of information we possess as well as the long time-frame over which we have it at the household level. Our purchasing data are from the Nielsen Homescan Panel, which is comprised of a demographically-representative set of consumers that provides, for each purchase transaction of a grocery item, the universal product code (UPC), the price paid, and the date of purchase. Overall, we observe over 123 million transactions made by consumers between 2002-2007. In addition, the data contain rich demographic information for each household, including household composition, race, income, and the census tract in which they live. Using the UPCs, we match each product with information from another data set that contains all nutritional information included on the product nutritional label. Together, these data provide extensive information on the nutritive bundles households purchase and the prices paid for all goods.

Existing researchers using scanner data have typically had access to data that is more limited in time or in the breadth of information than the data used in this analysis. For example, Dubois et al. (2014) use a similar scanner dataset to construct international comparisons for the year 2005-06 only. They document and examine the reasons for nutritional differences across the US, UK and France and find that price differences and product composition differences play some role in driving cross-country food purchasing variation. These results suggest that price-based manipulations could have important impacts on household nutrient intake, however they do not examine how product and nutrient taxes would affect the distribution of consumer expenditures and nutrition. Allais et al. (2010) estimate a food demand system using French scanner data but have to aggregate at different cohort levels because the price information is only recorded for a subset of the observed households. Finkelstein et al. (2012) and Finkelstein et al. (2010) use similar data as well but only for 2006, and their analysis data do not include a complete set of purchased food products. ${ }^{2}$ In their examination of purchasing patterns over the lifecycle,

\footnotetext{
${ }^{2}$ Other researchers who have used scanner data to estimate demand models have focused on a specific category of products, such as beverages (Dharmasena and Capps, 2012; Lin et al., 2011; Zhen et al., 2011), snack foods (Kuchler et al., 2005), and dairy (Chouinard et al., 1998; Griffith et al., 2010). These analyses typically contain only one or a few years of data, do not examine substitution across groups, and/or aggregate the data to the product-month level or to the household-year level, which throws out a large amount of important demographic and price information. Aggregation also renders the estimates subject to biases that might arise from local composition changes that are correlated with price changes. Another strand of the demand literature uses household survey data combined with local price estimates from the American Chamber of Commerce Research Association (ACCRA) or from respondent reports (Yen et al., 2004; Duffey et al., 2010). The prices and respondent reports of foods purchased or consumed used in these analyses are likely to be far noisier than in our data. Finally, there is little attention paid to endogeneity issues with respect to prices in this prior work.
} 
Aguiar and Hurst (2007) use data only for Denver, covering the period January 1993 through March 1995, and they do not have nutritional information about the products purchased. ${ }^{3}$ The dataset we construct thus provides the opportunity to measure a more detailed set of information over a longer period of time than any existing demand study in the literature.

The second contribution we make is to partition the data into a joint product-nutrient space over which the demand model can be estimated. A core difficulty in estimating food demand models is that it is not possible to price the individual nutritional components of a good. That is, one cannot determine what part of the price of a good is due to the fat content and what part is due to the salt content. Prior research typically has addressed this issue either by separating different products into different nutrition groupings in an ad-hoc manner or by estimating models with the nutrients purchased from each product type as the outcome of interest in the demand model (Finkelstein et al., 2012). ${ }^{4}$ Neither method is completely satisfying, however, because the former relies on researcher judgements about how consumers segment products and the latter does not account for the fact that nutrients are correlated with each other within products, thus introducing a bias from omitted variables. We develop a new method for partitioning the product space into relevant nutritional groupings using cluster analysis. The motivation of this method is that nutrients tend to be correlated with each other in specific ways that define a set of relevant goods for a consumer. For example, high-fat snack foods also tend to be high-salt, while lower-fat snack foods contain higher levels of sugar. Our approach amounts to partitioning each product type into clusters of nutrient groupings that define a nutritionally-similar set of goods using the data, rather than making judgement calls about what the relevant different food groupings are. It also is possible for there to be several nutritional clusters for each product type. Clustering in this manner thus allows us to generate a set of nutritionally-bundled goods within each product group that define consumers choice sets in a parsimonious manner and that does not require us to assign a price to each nutrient.

Our analysis also contributes to a relatively large literature that focuses on estimating the price elasticity of demand for particular foods. ${ }^{5}$ These studies can be split into two groups. The first uses structural demand techniques to identify price elasticities of demand. As discussed

\footnotetext{
${ }^{3}$ In a related study examining lifecycle expenditures, Aguiar and Hurst (2013) use Consumer Expenditure Survey data that provide information about a wider variety of goods consumed but that do not have the specificity about food products purchased that characterize the Nielsen Homescan data.

${ }^{4}$ Alternatively, Dubois et al. (2014) model the joint product-nutrient space in such a way that the characteristics of products are fully subsumed into the nutrient space. While useful for the aggregate cross-country comparisons they employ, this method imposes restriction on the cross-price elasticities and does not allow one to examine product-specific price manipulations directly.

${ }^{5}$ See Andreyeva et al. (2010) for a review and meta-analysis of this literature. Most of the these studies use aggregate time-series data, with a smaller percentage using household-level data. A small minority use household scanner data, and these studies typically lack credible instruments for prices and do not allow for consumer substitution across products.
} 
above, data limitations and issues pertaining to price endogeneity have hampered these analyses. The second group uses variation from imposition of excise or sales taxes as natural experiments to examine how consumers respond to arguably exogenous price changes. While most states exempt food purchased in grocery stores from sales taxes, as of 2011, 35 states either include soda in the sales tax base and/or levy an excise tax on soda. The existing literature using these tax changes as natural experiments to identify the effect on soda demand find that soda is inelastic with respect to this tax variation (Powell et al., 2013; Fletcher et al., 2010a,b). ${ }^{6}$ However, these taxes tend to be quite small and they are unlikely to be salient to consumers because they usually are added onto the price at checkout (Chetty et al., 2009). In general, there is a lack of tax variation with which to identify the effect of taxing most products or nutrients. The lack of such policy variation highlights the need to examine how larger and more salient price changes might affect consumption using structural demand models that incorporate methods to identify causal price parameters. Furthermore, estimating a structural demand model permits a calculation of the welfare costs of imposing different types of taxes, which is useful in comparing the desirability of different tax regimes.

Finally, our paper contributes to the literature on commodity taxation and nutrition by examining taxes on different products and on nutrients themselves that incorporate both the ability of consumers to substitute across different goods in response to price changes but also the ability of consumers to reduce overall food consumption when prices rise. The inability to link purchases and prices together with nutritional content of food has precluded an examination of the effects of taxing specific nutrients, such as a sugar tax, in prior work, and existing studies are limited to an examination of the effects of taxing a specific product, like soda, or a group of products that have "undesirable" nutritional characteristics, like sugar-sweetened beverages. However, in order to inform the development of food-based taxes to affect nutrition, it is important to generate evidence on how consumer behavior will respond to taxing different types of products, product groupings and nutrients more broadly. For example, what will be the effect of taxing soda versus other highly-processed goods that previous work has argued contribute to rising obesity (Cutler et al., 2003)? How does taxing products affect consumer behavior differently than taxing nutrients? Does taxing sugar rather than taxing soda have a larger affect on nutrition, and how do fat taxes compare with sugar taxes in terms of changing consumer behavior and in terms of welfare costs of these taxes? We examine these

\footnotetext{
${ }^{6}$ Another 13 states tax snack foods, such as chips and pretzels, but we are unaware of any studies that examine the effect of these taxes. Some countries, such as Hungary, also tax foods high in sugar, fat, or salt. A recent meta-analysis of the international evidence suggests that these taxes have generally affected consumption in the predicted direction, but that in order to have a significant population health impact taxes in excess of 20\% are required (Mytton et al., 2012).
} 
questions directly by separately simulating the effects of a $20 \%$ tax on soda, sugar sweetened beverages (SSBs), packaged meals, snacks/candy, fat, sugar and salt on budget shares for our product-nutrient groups and on nutrient bundles purchased by households. By incorporating substitution effects across goods as well as the income effects due to these taxes, these simulations yield a comprehensive picture of how these product- and nutrient-specific taxes affect nutrition.

This paper is structured as follows. Section 2 introduces the different proprietary databases and describes how the analysis dataset was constructed. We then explain how the data are used to estimate the QUAIDS model. Section 3 discusses the estimated parameters of the demand system as well as the price and expenditure elasticities. Section 4 presents counterfactual simulations of the impact of product taxes for soda, SSBs, packaged meals, and snacks/candy and also nutrient taxes on fat, sugar, and salt on purchasing behavior and nutrition, and Section 5 concludes.

\section{Data and Empirical Model}

\subsection{Data}

The data we use for this analysis is constructed from several different databases that provide detailed information on food purchases over a multi-year period by American households. The core of the data set consists of records on over 123 million food purchase transactions made at grocery stores over the period 2002-2007. These data come from the Nielsen Homescan database. $^{7}$ The Nielsen Homescan data are collected from a demographically-representative panel of US households who are provided with a small scanner similar to ones used at grocery stores. We observe food purchases intended for at-home consumption made at a variety of stores, from traditional grocery stores, supermarkets and convenience stores to supercenters and warehouse clubs. Most purchases are identified using a unique Universal Product Code (UPC), a 12 digit barcode scanned by the retailer at the point of purchase. Households are required to scan the UPC barcode of each item purchased and record the price, date, and location of purchase as well as the quantity of each item bought. Non-UPC label items, such as fresh fruits and vegetables, are recorded manually by the households and also are included in our data and analysis. UPC-labeled items are automatically matched by Nielsen to an additional database that contains detailed product characteristics, such as brand, size, and price of the

\footnotetext{
${ }^{7}$ For additional information on the Nielsen Homescan data, see Todd et al. (2010).
} 
product. Prices are checked against store data in order to account for discounts and coupons. ${ }^{8}$ At the end of the week, households transmit their purchase data electronically to Nielsen. Participating households are not paid in cash but earn a set number of points with each data upload. Households are rewarded the longer they stay with the program, and those who already have been in the panel for at least six months receive a substantially larger number of points for each transmission. The points can be redeemed for products, so households have a strong incentive to upload their purchase data. Customers can redeem points for select merchandise from a product catalog, such as tools, electronics, toys or to enter sweepstakes. All households are in the sample for at least 10 months, and most stay in for under 5 years.

Participating households are recruited across 52 large markets (roughly corresponding to the largest Metropolitan Statistical Areas or MSAs in the US). Nielsen aims to maintain a nationally-representative panel, subject to additional weights. Thus, recruitment into the panel is ongoing, with observably similar refresher households replacing those who leave the sample.

Our data cover the years 2002-2007, which is a useful time period because it is not affected by the more recent economic downturn. While the relative stability of our analysis period is useful for the internal validity of our estimates, a potential concern is the extent of changes in the pattern of food purchases and diets between 2007 and today that would make our results more difficult to generalize. Over the last 15 years, diets were very similar for American consumers. For example Slining et al. (2013) find that most changes occurred on the beverage side (and not in food purchases) and disproportionately in children. Harding and Lamarche (2016) also find that the Great Recession did not have a significant impact in changing the pattern of shopping trips across this population. We note that as long as price and expenditure elasticities across different types of products did not substantially change over the past decade our estimates will be relevant to the current policy environment. We are unaware of any research exploring this question, but the relative stability of the food purchasing patterns of US households is at least suggestive that such changes were not large.

The Nielsen Homescan data do not contain any nutritional information about the products purchased. From Gladson and FoodEssentials, we obtained nutritional information at the UPC level for all products tracked by these companies. The data contain all nutritional information on the product nutrition facts panel by UPC code, including the amount of each nutrient and the entire ingredient list. While the nutrition data cover a large proportion of the total purchases made by households in the panel, about $35 \%$ of the transactions in our data cannot be matched

\footnotetext{
${ }^{8}$ Einav et al. (2010) discuss some of the technical issues that arise as a result of the price recording process.
} 
directly to products in the nutrition database. The products that cannot be matched directly typically consist of small, often generic, brands. In order to ascribe nutritional characteristics to these products, we developed a matching algorithm that assigns to each product the average per-serving characteristics within decreasingly narrow bins of similar products. We first match unmatched Nielsen products to products with nutritional information in the same "product module" with the same size, type, brand, product, flavor, variety and formula. ${ }^{9}$ This produces matches for an additional $15 \%$ of the transactions. We then alter the product characteristics used for matching to systematically broaden the set of potential match products. Details of the matching strategy and the proportion of the sample in each year matched using each set of characteristics are show in Table A-1. This algorithm produces nutritional estimates for between 96 and 98 percent of the products recorded in the Nielsen Homescan data, depending on the year. ${ }^{10}$ Furthermore, about $5 \%$ of the transactions are "random weight" or bulk foods, such as fruits, vegetables, and fresh meats, that are not tracked by Gladson or FoodEssentials. The nutritional content of these items was coded manually by name and integrated with the database using information from the USDA National Nutrient Database.

Although these data provide extremely detailed information about grocery purchases, there are some limitations of using these data to study nutritional outcomes. First, they do not include restaurant purchases (including fast food) or purchases made at vending machines, and any food consumed outside the home that is not purchased by the household at a store will not be included. Second, because we are using purchase data, we cannot observe consumption of the overall household or of different household members. Spoilage, wastage, and different eating patterns among different household members complicate extrapolations from purchasing behavior to individual consumption. Despite these limitations, we believe these data are appropriate for studying the effects of food taxes on nutrition. To the extent that these factors influence purchasing behavior and nutritive bundles, it is unlikely that changes in the food available within the household does not result in changes in nutrients consumed by household members. This is particularly true because over $2 / 3$ of calories are consumed in the home (Nestle, 2012).

The data allow us to control for a rich set of observables that capture detailed information about each household. Nielsen administers a yearly demographic survey to all participating

\footnotetext{
${ }^{9}$ Product modules are specific product designations that indicate small groups of similar products. For example, diet and regular soda are two product modules, as are canned apples and pears. There are numerous product modules in the data, and thus products within product modules are very similar to each other in terms of nutritional content.

${ }^{10}$ This algorithm is essentially the same as the one employed by Dubois et al. (2014) and resulted from a joint collaboration with the USDA.
} 
households that records their home address, household income, the education and race of the head of household, the age and labor supply for both male and female heads of households, the household composition and number of children. Our data do not include addresses, but we are given the census tract in which each household resides in each year. The summary statistics for the demographic variables are presented in Table A-2. Consistent with previous work using these data (e.g., Burda et al. (2012)), we find that certain sampling distortions remain relative to national averages. For example, in the data $31.8 \%$ of the male heads and $36.8 \%$ of the female heads are recorded as not employed. Similarly, we find that $28.5 \%$ of the sample reports a household income above $\$ 70,000$ compared to only $24.7 \%$ who report a household income of below $\$ 30,000$. These sample means reflect the relative attractiveness of participation in the panel to households of different demographic compositions. Since we control for these demographic characteristics in our empirical models, it is unlikely any differences between the Nielsen sample and a national sample will bias our estimates.

The Nielsen database does not contain information on the set of stores available to consumers. In order to characterize purchasing environments, we supplement our data with records from the National Establishment Time-Series (NETS) Database, compiled by Walls and Associates using data from the Dun and Bradstreet (D\&B) archival national establishment data (DUNS Marketing Information file, DMI). This database tracks over 40 million establishments nationwide, with information on their industries and location. We obtained data on the location of all stores at which one can buy groceries (i.e., all non-prepared foods) in each county in which a Nielsen respondent lives in the 52 markets. For each household, we construct the detailed distribution of stores by geographic distance. We categorize stores as supermarkets, grocery stores and convenience stores and count the number of stores within 1/4 mile, 1/2 mile, $3 / 4$ mile, 1 mile, $11 / 2$ miles and 2 miles of the centroid of a household's residence census tract.

\subsection{Product Classification}

One of the challenges involved in building a comprehensive food demand model consists in choosing the level of product aggregation that leads to a realistic, yet computationally feasible structural demand system. We aggregate over the joint product-nutrient space, which allows us to specify a parsimonious set of groups over which to estimate our model while permitting flexibility in the nutritional content of goods consumers can purchase of each product type. Our approach proceeds as follows: 
1. We characterize each product in terms of the nutrients it contains.

2. For each product category we partition the set of products in that category into $k$ distinct product-nutrient groups using a $k$ - median clustering algorithm.

3. For each product category we choose the "optimal" number of $k$ product-nutrient groups using an algorithm that finds a (locally) optimal solution by comparing different clustering configurations using a metric referred to as "silhouette" validation (Rousseeuw, 1987). This process finds the set of nutrient-product clusters that maximize the average silhouette value within each product group, which amounts to determining the $k$ groupings that best separate the products into distinct nutritional clusters within each product group. One can think of the silhouette value as an objective function designed to measure the amount of separation between clusters. ${ }^{11}$

This procedure leads to a set of 33 mutually exclusive product-nutrient groups. The groups are constructed by partitioning Nielsen's 14 broad product categories, which roughly correspond to the major food areas a customer is likely to encounter in the store. These categories are fruits/vegetables, cold beverages, warm beverages, soda, packaged meals, grains/pasta/bread, canned food/sauce, cereal/breakfast items, other dairy (such as yogurt and cheese), meat, condiments, snacks/candy, milk and baking goods. We then analyze the nutritional content of each UPC in each of the 14 categories in terms of the most important and most salient nutritional items recorded on the nutritional panel of each product: calories, calories from fat, total fat, cholesterol, salt, carbohydrates, sugar and protein. Using these nutrients, we perform a k-median clustering at the UPC level separately for each of the 14 product categories. This clustering separates the 14 initial product groups into the 33 distinct product-nutritional clusters used in our analysis.

Figure 1 maps the average household budget in terms of the 14 major expenditure categories. Additional details on budget shares and prices for each of the 33 product-nutrient groups is available in Table 1. These tabulations demonstrate the comparatively large budget share of snacks and candy (15.6\%), meat (12.8\%), soda (5.3\%), and packaged meals (7.5\%), relative to fruits and vegetables (9.1\%). In Figure 1, darker rectangles correspond to more expensive product categories as measured by the price per ounce. Products with a higher share of the household food budget also tend to be more expensive. Meat/protein is twice as expensive as fruits and vegetables per ounce, while snacks and candy are over $21 / 2$ times as expensive.

\footnotetext{
${ }^{11}$ More details of this procedure are provided in Online Appendix B and are described in Rousseeuw (1987) and Jain and Dubes (1988).
} 
Table 2 lists the median nutrient quantity per serving for each of the 33 joint productnutrient cluster groups in the data. Packaged meals and meat stand out relative to the other food categories as having the most calories, calories from fat, total fat, salt, cholesterol and protein. Packaged meals also have a large amount of carbohydrates (along with cereal, breakfast and grain, pasta, bread). Compared to a serving of fruits and vegetables, a serving from a packaged meal has about 5 times the number of calories. Soda, which has almost no nutritional value, dominates all other food items in terms of sugar per serving, with 3 times the amount found in a serving of fruits and vegetables, milk, candy or breakfast cereal. Two of the cold beverage categories also are high in sugar, which together with soda explains the intense policy focus on sugar-sweetened beverage prices. However, several other categories, such as cereal and snacks/candy, also have substantial sugar content that suggests a SSB tax would be imperfectly targeted at high-sugar goods. In particular, snacks and candy, which correspond to the largest share of a household's at-home food budget, are characterized by a large number of calories and a significant amount of salt and sugar in spite of the limited nutritional value.

Table 2 additionally shows that within the 14 aggregate product categories, there are substantial differences across nutritional groups. These differences are highlighted by the category descriptions shown in Table 1, which broadly describe the products in each product-nutrient group. Furthermore, Appendix Table A-3 presents inter-quartile ranges of each nutrient and demonstrates that the nutrients that provide the key distinguishing characteristics across groups do not overlap. The bands of nutrients within groups also are in general small, which suggests there is little scope for within-group product substitutions that will allow one to purchase substantively different nutritive goods within each group. That the product groups are separated according to specific nutrients and that there is little nutrient variation within group is a direct outgrowth of the k-median clustering, which partitions the product space into nutritionallydistinct clusters.

There is considerable variation in the types of nutritional clusters across product groups. The soda category, for example, can easily be described as consisting of two groups of products: zero calorie / zero sugar soda ("diet-soda") and high calorie / high sugar soda ("classic" soda). In contrast, most groups exhibit clustering around certain nutrients. For example, the grain, pasta and bread category consists of a group of high-calorie but low-salt products (pasta) as well as two other groups of products containing substantially fewer calories per serving but also containing a lot of salt. These two high-salt, low-calorie groups are themselves distinguished by the amount of fat in the products, with buns, pastries and specialty bread having more fat 
than sliced bread. Similarly for fruits and vegetables, there is a high-calorie and low-salt group (fresh fruit), a low-calorie and low-salt group (fresh vegetables), and a high-salt group (canned vegetables and fruit). Taxing salt therefore could lead to more calories being consumed from certain types of grains, bread, and pasta and fruits and vegetables. These trade-offs are likely familiar to most households who are routinely facing the problem that minimizing the amount of one nutrient (e.g. fat) requires them to consume much larger amounts of another nutrient (e.g. salt or sugar). Ultimately, such trade-offs represent the chemical reality of product formulation, where reducing one ingredient requires the manufacturer to increase the amount of another in order to preserve the attractiveness of the product to the consumer. Table 2 shows that this trade-off is important for most of the product groups we consider. The ability to model the joint product-nutrient space in a parsimonious manner that also reflects the types of choices households likely face when shopping without having to rely on judgement calls about product classifications we believe represents an important contribution to food demand modeling.

\subsection{Empirical Methodology: QUAIDS Model}

The aim of this paper is to evaluate counterfactual policy changes for which few if any natural experiments exist. We adopt a utility-derived structural approach that will allows us to use estimated price and income effects to simulate the effect of product and nutrient taxes. A nonparametric analysis of the relationship between log expenditure and income, which is available upon request from the authors, indicates that all product groups have either linear or quadratic Engel curves. This result suggests a rank 3 demand model. Restricting attention to the class of exactly aggregable demand systems, the maximum rank of such demand systems is 3 (Deaton, 1981). Following Banks et al. (1997), the quadratic nature of the Engel curves argues for a demand model that is linear in log real expenditure and log real expenditure squared. In particular, this class of models has the attractive feature that it allows households at different points of the income distribution to have different marginal consumption responses to the same tax.

We focus on rank 3 demand systems with indirect utility:

$$
\ln V(\mathbf{p}, m)=\left\{\left[\frac{\ln m-\ln a(\mathbf{p})}{b(\mathbf{p})}\right]^{-1}+\lambda(\mathbf{p})\right\}^{-1},
$$

where $\mathbf{p}$ denotes the vector of product group prices (in dollars per ounce) for each of the $i=1 \ldots K$ product categories (with $K=33$ ), and $m$ denotes the total expenditure on grocery purchases for at-home consumption for the household in the month. Moreover, let $w_{i}$ denote 
the budget share of product group $i$. Then,

$$
\ln a(\mathbf{p})=\alpha_{0}+\sum_{i=1}^{K} \alpha_{i} \ln p_{i}+\sum_{i=1}^{K} \sum_{j=1}^{K} \gamma_{i j} \ln p_{i} \ln p_{j}
$$

is a price index (in translog form),

$$
b(\mathbf{p})=\prod_{i=1}^{K} p_{i}^{\beta_{i}}
$$

is the Cobb-Douglas price aggregator, and

$$
\lambda(\mathbf{p})=\sum_{i=1}^{K} \lambda_{i} \ln p_{i}
$$

is a function of prices $\mathbf{p}$, with $\sum_{i=1}^{K} \lambda_{i}=0$.

The system of budget share equations for the product groups is given by:

$$
w_{i}=\alpha_{i}+\sum_{j=1}^{K} \gamma_{i j} \ln p_{j}+\beta_{i} \ln \frac{m}{a(\mathbf{p})}+\frac{\lambda_{i}}{b(\mathbf{p})}\left(\ln \frac{m}{a(\mathbf{p})}\right)^{2}
$$

We estimate this model using the purchase/nutrition data described in Section 2 aggregated to the household-month-product-nutrition cluster group level. This aggregation leads to 34,245,832 observations. Aggregating the data in this manner has several advantages. First, using monthly budget shares minimizes problems associated with storage that plague studies using highfrequency shopping data. Monthly data at the product-nutrition cluster group level also decreases the prevalence of zeros, whereby households have no purchases of the given group in the month. Finally, using monthly data rather than longer horizons, such as quarterly data, makes it more likely that the average prices used reflect the prices actually faced by the household in that time period.

Letting $w_{i, h, t}$ denote the budget share of group $i$ for household $h$ in month $t$, the model above gives rise to the following structural system of estimating equations:

$$
w_{i, h, t}=\alpha_{i, h, t}+\sum_{j=1}^{K} \gamma_{i j} \ln p_{j, h, t}+\beta_{i} \ln \frac{m_{h, t}}{a\left(\mathbf{p}_{\mathbf{h}, \mathbf{t}}\right)}+\frac{\lambda_{i}}{b\left(\mathbf{p}_{\mathbf{h}, \mathbf{t}}\right)}\left(\ln \frac{m_{h, t}}{a\left(\mathbf{p}_{\mathbf{h}, \mathbf{t}}\right)}\right)^{2}+u_{i, h, t},
$$

where $u_{i, h, t}$ is an iid error term and $\mathbf{p}_{\mathbf{h}, \mathbf{t}}$ denotes the vector of prices faced by household $h$ in month $t$.

For computational simplicity, we approximate the term $a\left(\mathbf{p}_{\mathbf{h}, \mathbf{t}}\right)$ by the Stone price index 
(Decoster and Vermeulen, 1998):

$$
a\left(\mathbf{p}_{\mathbf{h}, \mathbf{t}}\right)=\sum_{k=1}^{K} w_{k, h, t} \ln \left(p_{k, h, t}\right)
$$

and as above, $b\left(\mathbf{p}_{\mathbf{h}, \mathbf{t}}\right)=\prod_{i=1}^{K} p_{i, h, t}^{\beta_{i}}$ is a Cobb-Douglas price aggregator.

Household-level heterogeneity is introduced in the structural model through the groupspecific intercepts $\alpha_{i, h}$, which are allowed to depend linearly on both observable and unobservable household characteristics:

$$
\alpha_{i, h, t}=\tilde{\alpha}_{i}+\mu_{h}+\pi_{i} \mathbf{Z}_{\mathbf{h}}+\delta_{t}
$$

In equation (8), $\tilde{\alpha}_{i}$ is a product-nutrition cluster group intercept, $\mu_{h}$ is a market fixed effect (indexed by $h$ to indicate that we track the location of each household), and $\mathbf{Z}_{\mathbf{h}}$ is an extensive set of household-level demographics, including household income, male and female head education, age, labor supply, race, household size, and family composition. These variables are shown in Table A-2. We also include in $\mathbf{Z}_{\mathbf{h}}$ the purchasing environment controls discussed in Section 2.1. Common macroeconomic fluctuations are controlled for with the inclusion of month and year fixed effects $\delta_{t} \cdot{ }^{12}$

Estimating this system of structural equations involves solving two econometric problems. First, instruments are required to identify the parameters of interest, since in general $E\left(u_{i, h, t} \mid p_{j, h, t}, m_{h, t}\right) \neq 0$. The endogeneity of prices and expenditure comes from a straightforward simultaneous equations problem. If there is unobserved demand heterogeneity or local demand shocks that are correlated with local prices or with household expenditure levels, then prices and expenditures are endogeneous. The instruments used thus need to be correlated with prices and expenditures but uncorrelated with unobserved demand heterogeneity and demand shocks, conditional on the other controls in the model. Second, due to the large sample size, a computationally-efficient approach is required for solving the system of 33 structural equations.

Our choice of instruments is informed by the fact that prices are typically set by stores at the market level. At the same time, stores purchase the majority of their products from national manufacturers who typically charge a uniform wholesale price. Thus, store level prices can be seen as the combination of market level factors and production cost factors common across markets. If we assume that the market-level pricing factors are independent across markets once

\footnotetext{
${ }^{12}$ We also have estimated models using month-by-year fixed effects and the estimates are virtually identical. These results are available upon request.
} 
the common production cost is accounted for, we can use the average price of each product across other markets as instruments (Hausman et al., 1994; Nevo, 2003). ${ }^{13}$ These prices are unlikely to be influenced by factors affecting only local demand variation, and any nationallevel demand shifts are accounted for by the year and month fixed effects. We construct price instruments by computing the average price of a product identified at the UPC-level in the same month and year in all other markets other than the one the consumer has made the purchase in. These prices then are aggregated at the year-month-product-nutrition cluster group level.

Additionally, we use local macroeconomic variation to identify expenditure coefficients, which assumes that expenditure is related to a non-linear function of market real income (Blundell and Robin, 1999), an index of market housing prices (Campbell and Cocco, 2007), and market unemployment (Attanasio et al., 2009). We approximate the relationship between log expenditure and log monthly per-capita market income, log quarterly housing prices, and log monthly unemployment by a second order polynomial expansion that includes squared terms and interactions between all of these variables. ${ }^{14}$ For both prices and expenditures, the first stage residuals are added as additional regressors to the estimating equations (Hausman, 1978).

The first stage price estimates are shown in Appendix Tables A-4, A-5, A-6, and the expenditure first stage is shown in Appendix Table A-7. For all instruments, the first stages are strong in the sense that the instruments are highly correlated with the endogeneous independent variable. For prices, the own price instruments are universally close to 1 and are highly statistically significant, using standard errors that are clustered at the census tract level. The expenditure instruments also are strong, with a first-stage F-statistic of 24.92.

Computationally, estimation of the system of 33 structural equations is complicated by the non-linearity of the specification. However, if we condition on $b\left(\mathbf{p}_{\mathbf{h}, \mathbf{t}}\right)$, the system of budget shares given in equation (6) is linear in the unobserved parameters $\tilde{\alpha}_{i}, \mu_{h}, \pi_{i}, \delta_{t}, \gamma_{i j}, \lambda_{i}$ (recall that in our specification $a\left(\mathbf{p}_{\mathbf{h}, \mathbf{t}}\right)$ is approximated by the Stone price index and does not depend on unknown parameters). This suggests a recursive estimation approach (Blundell and Robin, 1999; Lecocq and Robin, 2006). Given an initial guess of the $\beta_{i}$ parameters, estimates of the $\tilde{\alpha}_{i}, \mu_{h}, \pi_{i}, \delta_{t}, \gamma_{i j}, \beta_{i}, \lambda_{i}$ parameters can be obtained from a linear moment estimator. We then use the estimated $\beta_{i}$ parameters to update the value of $b\left(\mathbf{p}_{\mathbf{h}, \mathbf{t}}\right)$ until convergence is reached across iterations. The convergence threshold we use is that the maximum change in each $\beta_{i}$

\footnotetext{
${ }^{13}$ Finkelstein et al. (2012) uses a weighted average of prices within each respondent's market and month, where the weights are the inverse distance from the respondent's census tract. While this instrument addresses certain endogeneity issues related to individual demand heterogeneity, it does not address endogeneity coming from market-level demand shocks as well as unobserved heterogeneity correlated across space within a market.

${ }^{14}$ Monthly per-capita income come from the US Bureau of Economic Analysis, housing prices are from the Federal Housing Finance Agency's Home Price Index, and unemployment rates come from the US Bureau of Labor Statistics.
} 
across iterations must be less than 0.0001 in absolute value.

Additivity implies the following parameter restrictions on the system of budget share equations: $\sum_{i=1}^{33} \hat{\beta}_{i}=0, \sum_{i=1}^{33} \hat{\lambda}_{i}=0$ and $\sum_{i=1}^{33} \hat{\gamma}_{i k}=0$ for all $K$ products. In principle, one could impose these parameter restrictions and estimate the model by maximum likelihood or omit one category from the estimation and use these restrictions to solve for the parameters from the omitted product group. Instead, we estimate the model using all of the product groups and then test the parameter restrictions. In all cases, our estimates are consistent with these restrictions. ${ }^{15}$

Another identification concern arises when examining the role of purchasing environments in consumer shopping behavior. Since stores do not locate randomly with respect to consumer demand, it is very likely that the proximity of different store types is related to unobserved aspects of consumer demand. To address this problem, we include in equation (6) census-tractlevel means of each of the purchasing environment measures. Thus, the purchasing environment coefficients are identified off of changes in these environments from store entry and exit over time. This approach is conceptually similar to controlling for census tract fixed effects (Lecocq and Robin, 2006), but with thousands of census tracts, it is not possible to include them in the model. Census-tract-level means control for any unobserved demand heterogeneity that is fixed over time within tracts and that is correlated with store locations.

A final potential problem with our empirical strategy is the ability for within-group substitution, especially when a given nutrient is taxed. We argue this is not a first-order issue in this study because the method we use to split up product groups according to nutrient clusters leads to relatively homogenous groups in terms of their nutritional composition. This is shown in Appendix Table A-3. The within-cluster variation in most nutrients is far smaller than the cross-cluster variation, leaving little ability for consumers to purchase products within each group that are nutritionally-different. We also note that if there is within-group substitution, it will cause us to understate the effectiveness of nutrient-specific taxes relative to productspecific taxes. Below, we show that nutrient-specific taxes have much larger effects on behavior than do product-specific taxes; this result may slightly understate the relative effectiveness of nutrient-targeted taxes. Finally, our demand model is far more flexible in allowing for substitution patterns than prior work in this area that has examined the role of commodity taxation in driving purchasing behavior of consumers.

The expenditure elasticities and the uncompensated price elasticities play a central role in

\footnotetext{
${ }^{15}$ In particular, we find $\sum_{i=1}^{33} \hat{\beta}_{i}=0, \sum_{i=1}^{33} \hat{\lambda}_{i}=0$, and $\sum_{i=1}^{33} \hat{\gamma}_{i k}$ is between 0 and $2 \times 10^{-7}$ in absolute value for each product.
} 
our structural demand model. For two products $i$ and $j$, the procedure described above produces estimates of $\hat{\beta}_{i}, \hat{\gamma}_{i, j}, \hat{\lambda}_{i}$. Let $\hat{\Sigma}$ be the (partial) asymptotic covariance matrix corresponding to these three coefficients. The expenditure elasticity for product $i$ is given by:

$$
\epsilon_{i, h, t}=1+\frac{\beta_{i}}{w_{i, h, t}}+\frac{2 \lambda_{i}}{w_{i, h, t} b\left(\mathbf{p}_{\mathbf{h}, \mathbf{t}}\right)} \log \left(m / a\left(\mathbf{p}_{\mathbf{h}, \mathbf{t}}\right)\right) .
$$

The estimated variance of the expenditure elasticity is then given by:

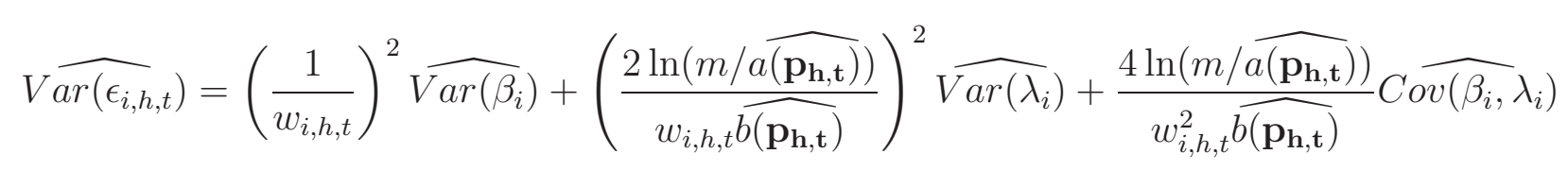

The cross-price elasticities are given by:

$$
\epsilon_{i, j, h, t}=-\frac{\widehat{\beta}_{i} w_{j, h, t}}{w_{i, h, t}}+\frac{\widehat{\gamma_{i, j}}}{w_{i, h, t}}-\mathbb{I}(i=j)-\widehat{\lambda}_{i}\left(\frac{2 \ln \left(m / \widehat{a\left(\mathbf{p}_{\mathbf{h}, \mathbf{t}}\right)}\right)}{\widehat{b\left(\mathbf{p}_{\mathbf{h}, \mathbf{t}}\right)}} \frac{w_{i, h, t}}{w_{j, h, t}}\right)-\widehat{\lambda}_{i} \widehat{\beta_{j}} \frac{\left(\operatorname { l n } \left(m / \widehat{\left.a\left(\mathbf{p}_{\mathbf{h}, \mathbf{t}}\right)\right)^{2}}\right.\right.}{w_{i, h, t} \widehat{b\left(\mathbf{p}_{\mathbf{h}, \mathbf{t}}\right)}}
$$

where $\mathbb{I}(i=j)=1$ if $i=j$ and 0 otherwise.

Define the following $3 \times 1$ vector $\hat{g}$ :

$$
\hat{g}=\left(\begin{array}{c}
-\frac{w_{j, h, t}}{w_{i, h, t}}-\hat{\lambda}_{i} \frac{\left(\ln \left(m / a \widehat{a\left(\mathbf{p}_{\mathbf{h}, \mathbf{t}}\right)}\right)^{2}\right.}{w_{i, h, t} b\left(\mathbf{p}_{\mathbf{h}, \mathbf{t}}\right)} \\
\frac{1}{w_{i}} \\
\frac{\ln \left(m / a \widehat{\left(\mathbf{p}_{\mathbf{h}, \mathbf{t}}\right)}\right)}{w_{i, h, t} \widehat{b\left(\mathbf{p}_{\mathbf{h}, \mathbf{t}}\right)}}\left(-2 w_{j, h, t}-\hat{\beta}_{j} \ln \left(m / \widehat{a\left(\mathbf{p}_{\mathbf{h}, \mathbf{t}}\right)}\right)\right.
\end{array}\right)
$$

By the Delta Method, the estimated variance of the cross-price elasticity is (approximately) given by:

$$
\widehat{\operatorname{Var}\left(\epsilon_{i, j}\right)} \approx \hat{g}^{\prime} \hat{\Sigma} \hat{g}
$$

Below, we report average elasticities, which are computed over all households and time periods. Average elasticities are accompanied by average standard errors that are calculated using these variance formulas. Because the elasticities are functions of the parameters and of the data, we need to calculate standard errors that incorporate the variability coming from both of those sources. We do this by first calculating the standard error for each observation, using the standard errors from the QUAIDS model estimates that are clustered at the census tract level. We then take the average of these standard errors across all households and time periods. 


\section{Estimation Results}

\subsection{Elasticities}

Our structural model estimates a 33-equation demand system, leading to over 1,000 estimated elasticities. The full set of elasticity point estimates is available in Appendix Tables A-8, A-9, A-10, while the full set of standard errors is available from the authors. In Table 3, we focus in on the average own-price and expenditure elasticities. A bar chart of these elasticities is presented in Figure 2.

The own-price elasticities reveal that most products are fairly price inelastic. Soda, milk and cold beverages provide the exception. The price elasticity of the two soda groups are -2.26 and -2.20 , and the elasticities for cold beverages range between -1.81 and -2.06 . In a review of the literature, Powell et al. (2013) report an elasticity for sugar-sweetened beverages of about -1.21. Andreyeva et al. (2010) collect soft drink elasticity estimates from studies between 1938 and 2007 and find elasticities that range between 0.13 and 3.18 in absolute value. Our estimates show these products to be on the higher end but not out of the range of elasticity estimates from the existing literature. The studies reviewed by these authors estimate the price elasticity from changes in state level taxes, which are very small and likely to suffer from low salience (Chetty et al., 2009), or using naturally-occurring price variation in structural models without adequately accounting for the endogeneity of prices. Our estimates are identified off of much larger price variation over a longer period of time, and we employ instruments that more credibly overcome problems associated with price endogeneity. These differences likely explain any divergence of our elasticity estimates from those in the existing literature.

Table 3 also shows fruits and vegetables to be rather elastic, with elasticities that range from -0.83 to -1.38. At the other extreme, meat, snacks, cereal, and pasta are fairly inelastic. Fruits and vegetables are between 2-5 times more price elastic than meat, grain/pasta/bread or breakfast foods. Overall, the elasticities vary substantially both between and within aggregate categories. Furthermore, two product groups in the breakfast and meat categories (High carbohydrate cereal and egg substitute-21; canned meat and eggs-23) have small positive elasticities but are economically insignificant. One group of packaged meals (salads and frozen meat-14) has a positive own-price elasticity of 0.12 , which still is small. As Figure 2 shows, this group also has a negative expenditure elasticity, suggesting that at least some of the packaged meals can be thought of as Giffen-like goods. The presence of a Giffen-like goods may be somewhat puzzling given the ongoing debate about whether Giffen goods exist. We underscore that these 
estimated elasticities are quite small: two of the three positive elasticities are under 0.025 , and the third is only 0.12 . While these elasticities all are statistically significantly different from zero at the $5 \%$ level, this reflects the precision of the estimates rather than economically-significant positive elasticities.

Table 3 reports average expenditure elasticities as well, and the results highlight the importance of including these elasticities when simulating consumer responses to different food-based taxes. For soda in particular, expenditure elasticities are greater than 4. These elasticities indicate that large income effects will generate sizable reductions in overall expenditures due to a tax on these products that would be missed by examining substitution patterns alone. We also find that one of the packaged meal categories (salads and frozen meat-14) and one of the snacks/candy categories (canned meat and eggs-23) are inferior goods, meaning that overall consumption might increase if you tax these goods. Depending on the size of this response, taxing packaged meals or snacks/candy could increase total purchases of different nutritional categories. All other products are normal goods, with income elasticities that vary considerably both between and within product categories.

The substantial variation in elasticities within product categories indicates that consumers respond differently to price changes for products within a category. While there are many additional dimensions of the product space that are not explicitly accounted for here, in our model product groups are distinguished by their location in the nutrition space. Consider the snacks and candy category. Within this category, the k-median algorithm partitions the products into two very different groups. One of the groups has lower median calories per serving than the other group (see Table 2), and it also has less fat and salt per serving. However, the lower-calorie group contains products that are higher in sugar. Thus, one of the groups can be thought of as saltier and fattier snacks (chips and cookies), while the other contain highersugar products (candy). Interestingly, the higher-sugar group has an own-price elasticity that is larger in magnitude (in absolute value). This begs the questions of whether there may be a systematic relationship between nutrients and elasticities. We explored this further in a series of multivariate correlation analyses: products higher in sugar and protein are significantly more price elastic, while products higher in carbohydrates are less price elastic. Though descriptive in nature, such correlations suggest that sugar taxes in particular might be an effective method to alter consumer purchasing behavior.

In order to get a sense of the patterns of cross-price elasticities, Table 4 presents symmetric matrices of own and cross-price elasticities for each aggregate category. The diagonals in 
each panel show the own-price elasticities (and are identical to those in Table 3), and the offdiagonals show the cross-price elasticities among all the nutrient clusters within product type. On the whole, these estimates show little evidence of within-product substitution behavior. Soda exhibits the most within-category substitution, with cross-price elasticities of 0.17 to 0.2. The cross-price elasticities for milk also are sizable, at 0.11 and 0.26 . For the remainder of the products, consumers do not respond to price changes by purchasing more (or less) of the same product with a different nutritional composition.

The estimates in Table 4 do not necessarily imply that cross-group substitution patterns are low, as it could be that substitution is more likely across product types than within product categories. Appendix Figure A-1 displays the full pattern of cross-price elasticities. The size of the rectangles corresponds to the magnitude of the cross-price elasticity, while the color denotes the sign. We notice a broad dispersion of magnitudes and signs for the off-diagonal elements of the cross-price elasticity matrix, suggesting that the substitution patterns are indeed more likely to occur across product groups. A close investigation of the standard errors revels that most of the elasticities also are statistically significant.

The complex pattern of complements and substitutes highlights that policy interventions need to be implemented with care, since the potential for unanticipated consequences resulting from a price intervention is inherent in the substitution pattern. In Appendix Figure A-2, we explore the cross-price elasticities in more detail for product groups 11-14, corresponding to soda and packaged meals. Soda is a substitute good for most other products, including fruits and vegetables, breakfast foods, meat and packaged meals. But, it is a complement for snacks and candy. While packed meals are own-price inelastic, they are complements for fruits and vegetables and grain/pasta/bread. The opposing pattern of signs for soda and packaged meals indicates that price changes are likely to have very different effects when applied to these two product groups. Soda is very own-price elastic and an increase in the price of soda increases the demand for many other food items. In contrast, packaged meals are own-price inelastic (and possibly a Giffen good), and an increase in their price reduces the demand for many other food items.

Our cross-price elasticity results do not imply that increasing the price of goods perceived to be unhealthy, such as soda or packaged meals, necessarily leads to consumers switching to more healthy options, such as fruits and vegetables. In the case of soda and packaged meals, we see responses that are polar opposites. Higher soda prices increase the demand for various other food items, while higher packaged meal prices decrease the demand for a range of food 
items. The response to price increases for all other food categories is somewhere in between. If we think of the household food consumption bundle before and after a price increase, we see that a price increase alters the composition of the bundle in a fairly complex fashion, typically increasing the demand for some product groups and decreasing the demand for others. The overall impact on nutrients, however, is unclear and needs to be simulated in a fashion similar to that in the next section of this paper. This also emphasizes the fact that it is potentially misleading to estimate single product demand models in order to infer the benefit of a nutrition policy on household nutrient consumption.

\subsection{Demographic Heterogeneity and Store Density}

Our model estimates also generate a large number of results relating demographic variables to preferences for the different food groups. While detailed tables are available from the authors, it is worth pointing out that we find a variety of demographic gradients for the different product groups. For example, shares of fruits and vegetables, packaged meals and snacks/candy increase with income, while soda, meat and milk purchases decline with income. Thus, wealthier households spend over $7 \%$ more of their budget both on fresh fruits and vegetables as well as on packaged meals, potentially reflecting the presence of opposing forces: increased health awareness but also higher opportunity cost of time. These gradients point to a complex relationship between the distribution of nutrients and the distribution of income.

Shares of fruit and vegetables increase with education, while the soda share is uncorrelated with education, and snack/candy and meat purchases are negatively correlated with educational attainment. The product shares in the household food budget vary with age as well, with younger households consuming more fruits and vegetables. The share of consumption decreases with age but then increases again after retirement. Overall, however, the fruit and vegetable share remains lower for households above 65 than for households below 35 years of age. The shares of soda, packaged meals and snacks consumption increase with age but then decrease again at retirement. The share of meat consumption increases with age throughout.

Expenditure shares are strongly associated with female labor supply, with large differences between households with a working and a non-working female head. ${ }^{16}$ Households with a non-employed female head purchase more soda, fewer packaged meals, and less meat and snacks/candy. In contrast, non-employment of the male head of household does not have a statistically significant impact on the budget shares of the different products consumed. The

\footnotetext{
${ }^{16}$ Note that households in our data can have both a male and a female head.
} 
presence of young children (under 12 years of age) indicates an increased share of consumption spent on fruits/vegetables, cereals and milk and a lower share of expenditure allocated to soda, packaged meals or canned foods. This pattern may reflect parental concerns to provide healthier food options to their children.

A byproduct of our analysis is that we can provide evidence on the role of purchase environments in driving budget share allocations. Our model estimates the effect of one additional store of the given type in the given distance from the census tract centroid on the budget share, conditional on all of the other controls in the model. We find little relationship between the distance to stores and the consumption shares of the different products. With a large number of observations and small standard errors, very few coefficients are even statistically different from zero at conventional levels. Thus, our estimates can rule out even small effects of purchasing environments on budget shares of these goods. Our findings indicate that the food purchasing environment, as measured by the store density, is not a primary driver of food consumption and nutrition trends at this level of aggregation and for these consumers. ${ }^{17}$

\section{Tax Simulations}

Using the estimated structural demand model presented above, we construct policy counterfactuals surrounding the introduction of three types of taxes aimed at changing the behavior of households and encouraging healthier consumption. One type of tax is a product-specific tax, where a product group considered to have negative health impacts is identified and all products that are part of that group are taxed proportionally. We focus on taxes on soda, packaged meals and snacks/candy because they all are prevalent in the American diet and are high in fat, sugar, and salt.

We also examine the effect of introducing nutrient-specific taxes on fat, sugar, and salt. The taxable amount is directly proportional to the share of the specific ingredient in the product formulation. Consider a $12 \mathrm{fl}$. oz. can of Coca-Cola. It has 39g of sugar, $45 \mathrm{mg}$ of sodium and $0 \mathrm{~g}$ of fat. This also corresponds to 140 calories. Now consider a $12 \mathrm{fl}$. oz. can of Diet Coke. It has Og of sugar, $40 \mathrm{mg}$ of sodium, $0 \mathrm{~g}$ of fat and 0 calories. A fat tax will not affect the price of either product, a sugar tax will affect the price of the first product but not the second product, while a salt tax will affect the price of both products in proportion to their respective sodium contents.

\footnotetext{
${ }^{17}$ While our analysis does not find an impact of the purchasing environment as measured by store density, it is important to note that a much more subtle analysis of the food desert and food swamp landscape is required in other to make definitive statements on this issue. This analysis however lies outstide of the scope of our analysis.
} 
Nutrient-specific taxes have the potential benefit that they target the harmful nutrients more directly than product-specific taxes, but they also have the drawback that they might reduce consumption of healthier products due to substitution effects or due to correlations among different nutrients in these products. The third type of tax we consider is a tax on SSBs, which can be thought of as a hybrid that targets a subset of products that contain large amounts of sugar. This tax has received considerable attention in prior work, and we include it here in order to be able to compare our results with the existing literature.

Throughout, we simulate the effect of a $20 \%$ tax on products and nutrients. ${ }^{18}$ Because we lack data that allow us to model the supply-side, we are not able to consider the incidence of these taxes. Thus, when we are referring to a "20\% tax on soda," one can view this as a tax on soda that generates a $20 \%$ price increase. While the incidence of any such taxes we simulate are important in their own right, the existing literature on the incidence of commodity taxation tends to find tax pass-through rates close to 1 (Harding et al., 2012; Kenkel, 2005; Besley and Rosen, 1999). ${ }^{19}$ That the incidence of these taxes tends to fall on consumers suggests that ignoring the supply-side is not a large drawback in the short-run. ${ }^{20}$ We also do not consider issues pertaining to tax administration. This paper is focused on identifying the expenditure and nutritional effects of these taxes, but we acknowledge that how such taxes are structured and their administration could be very important in driving any impacts they may have (Chetty et al., 2009; Slemrod and Kopczuk, 2002). For the purposes of this analysis, we assume that taxes are remitted by wholesalers or on the raw nutrients themselves (e.g., a tax on refined sugar or iodized salt). This would largely eliminate salience issues because the tax amount would be reflected in the shelf price, but there still could be complications with evasion and avoidance, particularly if the taxes are not national in scope. ${ }^{21}$

Using the results from the estimated structural model, we simulate the effect of productspecific taxes by calculating, for each household month, the effect of a $20 \%$ increase in soda, packaged meals or snacks/candy on expenditures on each product-nutrient cluster group. We

\footnotetext{
${ }^{18}$ The $20 \%$ tax rate is somewhat arbitrary, but simulations using a $5 \%$ and $10 \%$ tax show the effects are extremely close to being linear in the tax rate. Thus, one can easily obtain the effect of a different-sized tax by rescaling our estimates.

${ }^{19}$ Bonnet and Requillart (2013) shows evidence that ad-valorem taxes are slightly under-shifted to consumers and excise taxes are slightly over-shifted. However, in both cases the pass-through of taxes to prices is close to 1.

${ }^{20}$ It also is possible that companies might reformulate their products in response to these taxes. We do not have the capability of including such endogenous responses in our model. Our estimates thus ignore any effects on nutrition that would come from making given products healthier. One can interpret our results as the effect of a small government or entity (such as a state) imposing a tax that would be too small to induce producers to reformulate their products. We also note that the nutrients we consider are very difficult to replace without altering the taste and desirability of most products. Any reformulation likely would increase the effect of these taxes on nutrition, however.

${ }^{21}$ See Lovenheim (2008); Goolsbee et al. (2010); Baughman et al. (2001); Lovenheim and Slemrod (2010); ? for estimates of the extent of cross-state tax avoidance with respect to cigarette and alcohol regulations.
} 
then calculate new budget shares and, for each of the 8 nutrient groups, calculate

$$
\Delta \text { Nutrient }=\Delta \text { Expenditure } * \frac{\text { Nutrient }}{\$} .
$$

That is, we multiply the estimated change in expenditure for the tax by the per-nutrient "price" of the good, separately for each product group. The expenditure changes are adjusted for the fact that the price of the taxed good is now higher, so we are not attributing increased expenditure on a good from a price increase to higher consumption. For nutrient-specific taxes, we engage in a similar exercise, but change the price of the products proportionally with respect to the amount of the nutrient included in its formulation. For example, a 20\% sugar tax will increase the price of fruits and vegetables by $7.84 \%$, the price of soda by $14.16 \%$, and the price of breakfast foods by $15.76 \%$.

Using the average amount of each nutrient in each product-nutrient cluster group, we first find the average change in price for the group if the price of the given nutrient increased by $20 \%$. We then estimate the effect on expenditures in each group from these price changes and calculate equation (9). The net effect of a given nutrient-specific tax contains own- and crossprice effects as well as expenditure effects from changes in several different product prices at once.

In Panel A of Table 5, we present the simulation results for a counterfactual $20 \%$ soda tax. We calculate expenditure, price and nutritional changes for all 33 product-nutrient groups, but we aggregate them to the original 14 product groups to present results for parsimony. Estimates for the full set of 33 groups are available from the authors upon request. We report the percent changes in expenditures and budget shares for each product as well as the overall effect on expenditure after the imposition of the tax. We further show the changes in nutrients purchased for each product group and for the overall shopping basket. In the panel titles, we report the average indirect utility cost of the tax, which is calculated from equation (1) for every household under both the original and new tax regimes. These indirect utility changes provide a measure of the utility cost of the product substitutions and changes in expenditure from each tax. $^{22}$ In order to translate these utility changes into dollar terms, we also calculate the equivalent variation (EV) in expenditures that would make households just as worse off as the given tax. For each tax, the EV thus is the lump sum expenditure reduction for each household that reduces indirect utility the same amount as the tax. All changes shown are averages over

\footnotetext{
${ }^{22}$ Our welfare calculations implicitly use a social welfare function that weights each household equally. See Banks et al. (1997) for a thorough treatment of welfare analysis with QUAIDS models.
} 
all households and time periods, which are computed at the individual level and use the full demand system. Thus, we would expect the simulations to provide more information than is contained in the average price and expenditure elasticities, as a result of both the aggregation process and the interactions between all products in the demand system.

Because of the large expenditure elasticity for soda, a $20 \%$ soda tax reduces soda expenditure by $3.92 \%$ and the share of soda in the household budget by $3.43 \%$. This reduces caloric intake by 2,231 calories and sugar intake by $675 \mathrm{~g}$. These changes translate to a reduction in caloric intake from soda by the equivalent of about 16 cans of Coca-Cola per month. As suggested by our results on the cross-price elasticities, soda taxes also induce a shift towards milk and snacks/candy and away from packaged meals and meat. These changes, along with a $1.66 \%$ reduction in total expenditures due to the soda tax, lead to declines in the purchase of each nutrient group. In particular, calories decline by $4.84 \%$ (4,779 calories) and sugar purchases decline by $10.35 \%$ (763.6g), the majority of which come from reductions in soda purchases. Declines in fat, salt, cholesterol, carbohydrates and protein also range from $2-4 \%$. The expenditure and price changes from this tax lead to an average decline in indirect utility of $2.5 \%$, or $\$ 21.22$ in equivalent variation. The average per-household monthly expenditure in our sample is $\$ 206.98$, so this tax reduces welfare the same amount as a $10.3 \%$ reduction in lump-sum food expenditures.

In Panel B of Table 5, we compare these simulation results to those obtained from imposing a $20 \%$ tax on SSBs. We model this tax as a $20 \%$ price increase for all groups that include sugarsweetened beverages, as such taxes typically are modeled and levied as a per-product tax rather than as a proportion of sugar in the product (Brownell et al., 2009; Finkelstein et al., 2012; Kamerow, 2010). This also makes the SSB and soda taxes more directly comparable. Because it impacts more products, the SSB tax has a larger impact on the types of products consumers purchase and on nutrition. A $20 \%$ SSB tax reduces total calories purchased by $8.4 \%$, most of which is occurring due to the almost $20 \%$ decline in sugar purchases. ${ }^{23}$ This price change also induces a small decline in the other nutrient categories, most of which is due to income effects. Interestingly, despite the large impact of the SSB tax on consumer purchasing behavior and nutrition, its effect on indirect utility compared to the soda tax is small, at $2 \%$. This utility reduction is akin to a $\$ 20.05(9.7 \%)$ reduction in expenditures. The reason for this result is that by increasing the prices of a broader set of goods, this tax induces less distortionary substitution

\footnotetext{
${ }^{23}$ This estimate is substantially larger than the closest prior estimate in the literature. Finkelstein et al. (2012) estimates a 20\% SSB tax would decrease per-capita daily calories by 24 . Our estimates translate into a daily per-capita reduction of 133 calories. We believe much of the difference in our estimates can be accounted for by the fact that their model does not allow for income effects of taxes, which we show are very important, especially for beverages.
} 
behavior that has high utility cost. Taxing the suite of sugary beverages limits the ability to substitute across these similar products, which produces larger changes in nutrition at a lower utility cost to consumers.

The effect of taxing another "unhealthy good," packaged meals, has a very different effect than taxing soda. The simulated effect of a $20 \%$ packaged meal tax is shown in Panel A of Table 6. Recall that packaged meal purchases are very own-price inelastic. Thus, households end up spending $7.96 \%$ more on packaged meals, and the share of packaged meals in the overall budget increases by $5.62 \%$. Due to the patterns of cross-group substitution, packaged meal taxes have only a small but positive effect on both total expenditure and on nutritional intake of the household. They also reduce indirect utility by $1.4 \%$ (\$13.23). Total calories increase by about $2.11 \%$ and sugar intake increases by $2.25 \%$. Note, however, that nutrients from packaged meals decline substantially. This reflects two forces: first, the tax leads to less overall expenditure on packaged goods and second, there is a sizable shift in expenditure within this category to the lower-fat and lower-salt group (as it has a positive own-price elasticity). Thus, packaged meal taxes would reduce the nutrients purchased coming from packaged meals. However, it would not support the purchase of more nutritious food bundles overall, even though this product group is quite unhealthy.

In Panel B, we show the effect of a $20 \%$ snack and candy tax. Recall that snacks and candy are also relatively price inelastic, although less so than packaged meals. A $20 \%$ tax on these goods causes an overall increase in budget share and expenditure, but there is a decline in the quantity of these items purchased. Calories, fat, sugar and salt, in particular, decline in this product group due to the tax. ${ }^{24}$ There also is a small shift towards fruits and vegetables and away from other dairy, canned food/sauces and soda. The overall impact of the candy/snack tax is to slightly reduce calories by $1.21 \%$ (1194.5 calories) and salt by $1.12 \%$. However, sugar, cholesterol and fat consumption increase slightly. The overall effect of this tax on nutrition therefore is somewhat ambiguous in sign, but it is likely to be small. As with packaged meal taxes, the indirect utility cost of this tax also is modest, at $2 \%$ or $\$ 20.04$ in equivalent variation. Compared with sizable nutritional effects of SSB and soda taxes, taxes on packaged meals and candy/snacks produce much smaller changes at a similar utility cost.

One potential complication with our tax simulation approach is that if consumers switch to lower-priced or lower-quality versions of the same goods, such as generic brands, in response

\footnotetext{
${ }^{24}$ The decrease in sugar from snacks and candy groups reflects both an overall reduction in the purchases of snacks and candy as well as a shift from group 28 (the higher sugar group) to group 29 (the lower sugar group).
} 
to product or nutrient taxes, expenditures could decline without affecting nutrition. However, we would be attributing the resulting expenditure declines to changes in total purchases within each product group rather than to changes in the types of products consumers buy within each group. This would cause us to over-state own price elasticities and thus the effect of the taxes we study on nutrition. Additional robustness checks (not reported here), which split the product categories by the median price, suggest that our results are not over-stating nutritional effects due to consumer substitution to cheaper goods with the same nutritive content. ${ }^{25}$

We now turn to simulation results from fat, sugar and salt taxes, which are shown in Table 7. The overall findings shown in the table point to these taxes being much more effective at altering nutritional bundles than are product-specific taxes, without generating a larger impact on total expenditures or indirect utility. This is suggestive that these taxes have far more potential to impact nutrition without causing much larger deadweight loss from distorting purchasing behavior.

In Panel A of Table 7, we show the effect of a $20 \%$ tax on fat. The fat tax reduces caloric intake by over $19 \%$ (18,984 calories), reduces fat purchases by $30.25 \%(1,424.5 \mathrm{~g})$, decreases cholesterol by $10.83 \%$ (1,223.5g), and reduces sodium by $10.63 \%$ (19,913.5mg). Despite these large changes, average indirect utility declines by only $2 \%$, equivalent to a $\$ 20.04$ expenditure reduction, which is comparable to the SSB, soda and candy/snack tax welfare losses. Purchase of dairy, fruits and vegetables, and meat/protein are reduced the most due to a fat tax. Households however increase their expenditure on soda by $3.16 \%$ and on other cold beverages by $1.76 \%$. Such substitution patterns lead fat taxes to only decrease sugar intake by $6 \%$. That expenditures on fruits and vegetables decrease and expenditures on soda increase suggest fat taxes do not unambiguously support better nutrition. Again, this result highlights the value of considering substitution effects across goods in response to food-based taxes.

Unlike a tax on fat, a $20 \%$ sugar tax has a very strong and unambiguously positive effect on nutrition at a small increase in utility cost of $2.6 \%$, or $\$ 21.37 .{ }^{26}$ It also has a very small overall effect on expenditure of $0.64 \%$. Although the relative difference in the utility cost between a soda and a sugar tax is only $\$ 0.15$, a sugar tax has a much larger impact on nutrients purchased. Our estimates show that monthly sugar consumption would drop by $16.41 \%$ (1,211.1g), with a

\footnotetext{
${ }^{25}$ A related concern is that individuals may shift to products with different nutritional content within groups due to these taxes. This is unlikely to be a first-order concern in our study because the nutritional clusters successfully separate products according to their nutrient composition, leading for little scope for such substitution (see Appendix Table A-3), and because any such substitution would cause us to understate the effect of nutrient- and product-specific taxes on household nutritional bundles.

${ }^{26}$ These simulations assume natural sugars in fruits and vegetables would also be taxed. This is consistent with the fact that from a nutritional standpoint, natural and processed sugars have similar biological effects. If we exclude fruits and vegetables from the sugar tax, we get slightly attenuated but similar results: calories decline by $17.8 \%$, total fat declines by $12.0 \%$, carbohydrates are reduced by $13.9 \%$ and sugar declines by $15.3 \%$.
} 
$18.54 \%(18,302.4)$ decline in total calories. The effect on fat and salt also are sizable, at $12.00 \%$ and $9.63 \%$ respectively. Total consumption of cholesterol and protein declines significantly as well. As Panel B illustrates, only about $14 \%$ of the reduction in sugar purchases comes from soda, which underscores the limits of taxing only this product. Instead, households reduce their sugar intake from all product groups. This broad-based reduction reflects both income and substitution effects: consumers purchase less overall and they also purchase healthier products. Recall that many goods high in sugar also have sizable amounts of other nutrients as well, such as fat and salt. We find that sugar taxes cause households to substitute both to healthier product groups and to healthier versions of the same product (e.g., diet versus regular soda).

The reason that sugar taxes are so effective is the same reason why the nutritional taxes in general are much more effective at altering nutritive bundles without causing a larger utility decline: they are very broad based. The vast majority of product groups and of products in general contain sugar, fat and salt. Sugar in particular is highly prevalent in American foods. Taxing these nutrients does not allow consumers to substitute to other goods that also contain these nutrients. Rather, they shift to healthier products and decrease overall consumption. Despite the fact that these taxes are predicted to cause changes in purchasing behavior that lead to large nutritional gains, their broad-based nature requires there to be much less of a behavioral response for a given amount of change in the nutritional bundle than for productspecific taxes. Thus, they are able to exert a large influence on nutrition at a similar welfare cost to the product-specific taxes we consider.

In the last panel of Table 7 , we investigate the counterfactual of imposing a $20 \%$ salt tax. Similar to the other nutrient taxes, the overall impact on nutrition is sizable: total salt purchased by the household decreases by $10.0 \%(18,792 \mathrm{mg})$ per month, which is equivalent to about 8 teaspoons of salt. While the biggest share of the reduction comes from condiments and spices (including salt products), substantial savings also are achieved from baking goods, snacks, and grains and pasta. This tax reduces total calories and fat by over $10 \%$ as well. However, soda expenditures increase by $8.3 \%$, which significantly reduces the effect of a salt tax on sugar. Again, this result underscores the importance of considering substitution behavior in assessing the effects of a given food-based tax. The cost of this tax in terms of indirect utility also is low, at $1.2 \%$ (\$10.95), suggesting that substantial nutritional gains in many areas could be achieved at minimal cost with a salt tax.

The discussion above suggests that when considering the choice between product- and nutrient-specific taxes, policy makers can achieve substantially larger improvements in nu- 
trition by implementing nutrition taxes, rather than product taxes. Both sets of taxes alter indirect utility similarly. But, nutrient taxes have far larger impacts on nutrition, which is the ultimate goal of these taxes. In fact it is rather remarkable that the implied utility cost of all these taxes is around 70 cents per household per day. While there are some unintended consequences of some of these nutrient taxes, such as higher soda consumption and decreased fruit and vegetable consumption, on the whole they lead to large reductions in purchases of most nutrient categories. One tax simulation stands out, however, which is the sugar tax. Not only is the indirect utility cost modest, it also leads to substantial reductions in the purchased amount of calories, sugar, fat, salt and cholesterol.

\section{Conclusions}

This paper investigates the degree to which food taxes can be used to support better nutritional choices among US households. The last few decades have seen a sharp rise in obesity and overweight in the US, which is now being referred to as the "obesity epidemic." With a large proportion of calories being consumed in the home, there has been a surprising lack of empirical examination of policy tools that can be used to induce consumers to purchase more nutritious food.

One reason for this gap in the literature is the need for detailed data on food purchases, prices, demographics, local store availability and nutrition as well as a parsimonious way to model the joint product-nutrient space. We construct the first data set of which we are aware that contains all of these components over a longer time horizon. We use 6 years of Nielsen Homescan data merged with the nutritional content of foods purchased that allows us to examine these policy issues with a level of detail and technical sophistication that previously was not feasible. One of the central contributions of this paper is to use the UPC-level nutritional information to find distinct nutrient clusters of goods within each product group that define the types of goods over which consumers can substitute. We then estimate a large utility-derived demand system, which identifies the price and expenditure elasticities across 33 product-nutrient groups at the household-month level. Using our structural demand estimates, we simulate the effect of $20 \%$ product taxes on soda, SSBs, packaged meals, and candy/snacks and $20 \%$ nutrient taxes on fat, salt, and sugar.

Our main finding is that nutrient-specific taxes have much larger effects on nutrition than do the product-specific taxes we study. However, they do not cost more in terms of consumer 
utility. While a $20 \%$ soda tax reduces sugar purchases by $10.35 \%$, it only reduces overall caloric intake by $4.84 \%$. Taxing packaged meals actually increases slightly overall caloric intake, even though this product group is the unhealthiest per serving. Taxing snacks/candy also has at most small impacts on the purchased nutritive bundle.

In contrast, taxing nutrients has large impacts on nutrition without producing larger welfare losses than product-specific taxes, largely because of the broad-based nature of these taxes. Among the three nutrient-specific taxes, sugar taxes are particularly effective. A 20\% sugar tax reduces sugar consumption by $16.41 \%$ while also reducing caloric intake by $18.54 \%$ and salt consumption by $9.63 \%$. Consumer indirect utility declines by $2.6 \%$, or $\$ 21.37$ in terms of lump sum expenditures, as a result, which is very similar to the utility costs of a soda tax and SSB tax. This implies that the utility cost to the consumers is only about 70 cents per household per day.

Overall, our estimates suggest that the use of nutrient-specific taxes could have an important effect in inducing healthier purchasing behavior among consumers. The results we present are consistent with theoretical arguments of the value of having broad-based taxes that are harder to avoid. Nutrients provide such a broad base, and our findings indicate that taxes on nutrients would do much more to support healthier nutritional choices than would taxes on products. The focus among public health officials and policy makers on the product-specific taxes (such as soda taxes) and even on nutrient-specific taxes on a small set of goods (such as an SSB tax) may be misplaced; broadening the tax base would achieve larger nutritional gains without causing larger overall distortions in household utility. 


\section{References}

Aguiar, M., Hurst, E., 2007. Lifecycle prices and production. American Economic Review 97 (5), $1533-1559$.

Aguiar, M., Hurst, E., 2013. Deconstructing lifecycle expenditure. Journal of Political Economy $121(3), 437-492$.

Allais, O., Bertail, P., Nichele, V., 2010. The effects of a fat tax on french households' purchases: A nutritional approach. American Journal of Agricultural Economics 92 (1), 228-245, 00051. URL http://ajae.oxfordjournals.org/content/92/1/228

Andreyeva, T., Long, M., Brownell, K., 2010. The impact of food prices on consumption: A systematic review of research on the price elasticity of demand for food. American Journal of Public Health 100 (2), 216-222.

Attanasio, O., Blow, L., Hamilton, R., Leicester, A., 2009. Booms and busts: Consumption, house prices and expectations. Economica 76, 20-50.

Banks, J., Blundell, R., Lewbel, A., 1997. Quadratic engel curves and consumer demand. The Review of Economics and Statistics LXXIX (4), 527-539.

Baughman, R., Conlin, M., Dickert-Conlin, S., Pepper, J., 2001. Slippery when wet: The effects of local alcohol access laws on highway safety. Journal of Health Economics 20 (6), 1089-1096.

Besley, T., Rosen, H., 1999. Sales taxes and price: An empirical analysis. National Tax Journal $52(2), 157-178$.

Blundell, R., Robin, J.-M., 1999. Estimation in large and disaggregated demand systems: An estimator for conditionally linear systems. Journal of Applied Econometrics 14, 209-232.

Bonnet, C., Requillart, V., 2013. Tax incidence with strategic firms in the soft drink market. Journal of Public Economics 106, 77-88.

Brownell, K., Farley, T., Willett, W., Popkin, B., Chaloupka, F., Thompson, J., Ludwig, D., 2009. The public health and economic benefits of taxing sugar-sweetened beverages. The New England Journal of Medicine 361, 1599-1605.

Burda, M., Harding, M., Hausman, J., 2012. A poisson mixture model of discrete choice. Journal of Econometrics 166, 184-203. 
Campbell, J., Cocco, J., 2007. How do house prices affect consumption? evidence from micro data. Journal of Monetary Economics 54 (3), 591-621.

Cawley, J., 2010. The economics of childhood obesity. Health Affairs 29 (3), 364-371.

Chetty, R., Looney, A., Kroft, K., 2009. Salience and taxation: Theory and evidence. American Economic Review 99 (4), 1145-1177.

Chouinard, H., Davis, D., LaFrance, J., Perloff, J., 1998. Fat taxes: Big money for small change. Forum for Health Economics \& Policy 10 (2).

Cutler, D., Glaeser, E., Shapiro, J., 2003. Why have americans become more obese? Journal of Economic Perspectives 17 (3), 93-118.

Deaton, A. (Ed.), 1981. Theory and Management of Consumer Behavior. Cambridge, Ch. Some Engel Curves.

Decoster, A., Vermeulen, F., 1998. Evaluation of the empirical performance of two-stage budgeting aids, quaids and rotterdam models based on weak separability, discussion Paper, Katholieke Universiteit Leuven.

Dharmasena, S., Capps, O. J., 2012. Intended and unintended consequences of a proposed national tax on sugar-sweetened beverages to combat the u.s. obesity problem. Health Economics 21 (6), 619-756.

Dubois, P., Griffith, R., Nevo, A., 2014. Do prices and attributes explain international differences in food purchases? American Economics Review 104 (3), 832-867.

Duffey, K., Gordon-Larson, P., Shikany, J., Guilkey, D., Jacobs, D. J., Popkin, B., 2010. Food price and diet and health outcomes: 20 years of the cardia study. Archives of Internal Medicine $170(5), 420-426$.

Einav, L., Leibtag, E., Nevo, A., 2010. Recording discrepancies in nielsen homescan data: Are they present and do they matter? Quantitative Marketing and Economics 8 (2), 207-239.

Finkelstein, E., Fiebelkorn, I., Wang, G., 1998. Annual medical spending attributable to obesity: Payer and service-specific estimates. Health Affairs 28, w822?w831.

Finkelstein, E., Zhen, C., Bilger, M., Nonnemaker, J., Farooqui, A., Todd, J., 2012. Implications of a sugar-sweetened beverage (ssb) tax when substitutions to non-beverage items are considered. Journal of Health Economics 32, 219-239. 
Finkelstein, E., Zhen, C., Nonnemaker, J., Todd, J., 2010. Impact of targeted beverage taxes on higher- and lower-income households. Archives of Internal Medicine 170 (2), 2028-2034.

Flegal, K., Carroll, M., Kuczmarski, R., Johnson, C., 1998. Overweight and obesity in the united states: Prevalence and trends, 1960-1994. International Journal of Obesity and Related Metabolic Disorders 22, 39-47.

Fletcher, J., Frisvold, D., Tefft, N., 2010a. Can soft drink taxes reduce population weight? Contemporary Economic Policy 28 (1), 23-35.

Fletcher, J., Frisvold, D., Tefft, N., 2010b. The effects of soft drink taxation on soft drink consumption and weight for children and adolescents. Journal of Public Economics 94 (1112), 967-974.

Goolsbee, A., Lovenheim, M., Slemrod, J., 2010. Playing with fire: Cigarettes, taxes, and competition from the internet. American Economic Journal: Economic Policy 2 (1), 131-154.

Griffith, R., Nesheim, L., O'Connell, M., 2010. Sin taxes in differentiated product oligopoly: an application to the butter and margarine market, cEMMAP Working Paper No. CWP37/10.

Harding, M., Lamarche, C., 2016. "penalized quantile regression with semiparametric correlated effects: An application with heterogeneous preferences. Journal of Applied Econometrics.

Harding, M., Leibtag, E., Lovenheim, M., 2012. The heterogeneous geographic and socioeconomic incidence of cigarette taxes: Evidence from nielsen homescan data. American Economic Journal: Economic Policy 4 (4), 169-198.

Hausman, J., 1978. Specification tests in econometrics. Econometrica 46, 1251-1271.

Hausman, J., Leonard, G., Zona, J., 1994. Competitive analysis with differentiated products. Annals of Economics and Statistics 34, 159-180.

Jain, A., Dubes, R., 1988. Algorithms for clustering data. Prentice-Hall.

Kamerow, D., 2010. The case of sugar sweetend beverage tax. BMJ 341, 132-133.

Kenkel, D., 2005. Are alcohol tax hikes fully passed through to prices? evidence from alaska. American Economic Review Papers and Proceedings 95 (2), 273-277.

Kuchler, F., Tegene, A., Harris, M., 2005. Taxing snack foods: Manipulating diet quality or financing information programs? Applied Economic Perspectives and Policy 27 (1), 4-20. 
Lecocq, S., Robin, J.-M., 2006. Estimating demand response with panel data. Empirical Economics 31, 1043-1060.

Levi, J., Segal, L., St. Laurent, R., Rayburn, J., 2014. The state of obesity 2014. Tech. rep., Trust for America's Heath and the Robert Wood Johnson Foundation.

Lin, B.-H., Smith, T., Lee, J.-Y., Hall, K., 2011. Measuring weight outcomes for obesity intervention strategies: The case of a sugar-sweetened beverage tax. Economics \& Human Biology $9(4), 329-341$.

Lovenheim, M., 2008. How far to the border? the extent and impact of cross-border cigarette smuggling. National Tax Journal 61 (1), 7-33.

Lovenheim, M., Slemrod, J., 2010. The fatal toll of driving to drink: The effect of minimum legal drinking age evasion on traffic fatalities. Journal of Health Economics 29 (1), 62-77.

Must, A., Spadano, J., Coakley, E., Field, A., Colditz, G., Dietz, W., 1999. The disease burden associated with overweight and obesity. Journal of the American Medical Association 282, $1523-1529$.

Mytton, O., Clarke, D., Rayner, M., 2012. Taxing unhealthy food and drinks to improve health. British Medical Journal 344, 1-7.

Nestle, M., 2012. New data on calories reported as consumed. Food Politics Blog http://www.foodpolitics.com/2012/07/new-data-on-calories-reported-as-consumed/.

Nevo, A., 2003. New products quality changes, and welfare measures computed from estimated demand systems. The Review of Economics and Statistics 85, 255-275.

Ogden, C., Carroll, M., Curtin, L., Lamb, M., Flegal, K., 2010. Prevalence of high body mass index in us children and adolescents, 2007-2008. Journal of the American Medical Association $303(3), 242-249$.

Pi-Suyner, F., 1991. Health implications of obesity. American Journal of Clinical Nutrition 53, 1595S?1603S.

Powell, L., Chriqui, J., Khan, T., Wada, R., Chaloupka, F., 2013. Assessing the potential effectiveness of food and beverage taxes and subsidies for improving public health: a systematic review of prices, demand and body weight outcomes. Obesity Reviews 14 (2), 110-128. 
Rousseeuw, P., 1987. Silhouettes: A graphical aid to the interpretation and validation of cluster analysis. Computational and Applied Mathematics 20, 53-65.

Slemrod, J., Kopczuk, W., 2002. The optimal elasticity of taxable income. Journal of Public Economics 84 (1), 91-112.

Slining, M., Mathias, K., Popkin, B., 2013. Trends in food and beverage sources among us children and adolescents: 1989-2010. J Acad Nutr Diet 12, 1683-94.

Todd, J., Mancino, L., Leibtag, E., Tripodo, C., April 2010. Methodology behind the quarterly food-at-home price database, uSDA Technical Bulletin 1926.

Yen, S., Lin, B.-H., Smallwood, D., Andrews, M., 2004. Demand for nonalcoholic beverages: The case of low-income households. Agribusiness 30 (3), 309-321.

Zhen, C., Wohlgenant, M., Karns, S., Kaufman, P., 2011. Habit formation and demand for sugar-sweetened beverages. American Journal of Agricultural Economics 93 (1), 175-193. 
Table 1: Budget Shares and Prices

\begin{tabular}{|c|c|c|c|c|c|}
\hline Group & $\begin{array}{l}\text { Budget } \\
\text { Share }\end{array}$ & $\begin{array}{c}\text { Price Per } \\
\text { Ounce }\end{array}$ & $\begin{array}{l}\text { Aggregate } \\
\text { Category }\end{array}$ & $\begin{array}{l}\text { Budget } \\
\text { Share }\end{array}$ & Category Description \\
\hline 1 & 0.025 & 0.107 & \multirow{3}{*}{ Fruits \& Vegetables } & \multirow{3}{*}{0.091} & Fresh fruit \\
\hline 2 & 0.043 & 0.101 & & & Fresh vegetables \\
\hline 3 & 0.023 & 0.078 & & & Canned vegetables and fruit \\
\hline 4 & 0.016 & 0.029 & \multirow{4}{*}{ Cold Beverages } & \multirow{4}{*}{0.062} & Bottled water \\
\hline 5 & 0.025 & 0.047 & & & Orange juice \\
\hline 6 & 0.009 & 0.035 & & & Fruit and vegetable juice \\
\hline 7 & 0.012 & 0.055 & & & Sports drinks \\
\hline 8 & 0.002 & 0.091 & \multirow{3}{*}{ Warm Beverages } & \multirow{3}{*}{0.034} & Powdered drink mixes \\
\hline 9 & 0.021 & 0.308 & & & Coffee and tea \\
\hline 10 & 0.011 & 0.181 & & & Creamers \& higher-fat drinks \\
\hline 11 & 0.031 & 0.029 & \multirow{2}{*}{ Soda } & \multirow{2}{*}{0.053} & Diet soda \\
\hline 12 & 0.022 & 0.021 & & & Regular soda \\
\hline 13 & 0.020 & 0.170 & \multirow{2}{*}{ Packaged Meals } & \multirow{2}{*}{0.075} & Packaged dinners \\
\hline 14 & 0.055 & 0.211 & & & Salads and frozen meat \\
\hline 15 & 0.037 & 0.107 & \multirow{3}{*}{ Grain, Pasta, Bread } & \multirow{3}{*}{0.085} & Sliced bread \\
\hline 16 & 0.015 & 0.130 & & & Pasta \\
\hline 17 & 0.033 & 0.150 & & & Buns, pastries, specialty bread \\
\hline 18 & 0.008 & 0.130 & \multirow{2}{*}{ Canned Food, Sauce } & \multirow{2}{*}{0.040} & Condiments \\
\hline 19 & 0.032 & 0.170 & & & Canned soups \& sauces \\
\hline 20 & 0.034 & 0.161 & \multirow{2}{*}{ Cereal, Breakfast } & \multirow{2}{*}{0.053} & Cereal \\
\hline 21 & 0.019 & 0.221 & & & High-carb cereals \& egg substitute \\
\hline 22 & 0.107 & 0.171 & Other Dairy & 0.107 & \\
\hline 23 & 0.064 & 0.198 & \multirow{3}{*}{ Meat, Protein } & \multirow{3}{*}{0.127} & Canned meat \& eggs \\
\hline 24 & 0.014 & 0.159 & & & Random weight meat \\
\hline 25 & 0.050 & 0.191 & & & Packaged meat \\
\hline 26 & 0.020 & 0.481 & \multirow{2}{*}{ Condiments, Spices } & \multirow{2}{*}{0.040} & Peanut butter, jelly, syrup \\
\hline 27 & 0.019 & 0.210 & & & Mayonnaise, dressing \\
\hline 28 & 0.061 & 0.317 & \multirow{2}{*}{ Snacks, Candy } & \multirow{2}{*}{0.155} & Candy \& chocolate \\
\hline 29 & 0.095 & 0.193 & & & Chips, cookies, crackers \\
\hline 30 & 0.029 & 0.024 & \multirow{2}{*}{ Milk } & \multirow{2}{*}{0.047} & Milk \\
\hline 31 & 0.018 & 0.043 & & & $1 / 2$ and $1 / 2$, soy milk, chocolate milk \\
\hline 32 & 0.006 & 0.064 & \multirow{2}{*}{ Baking Goods } & \multirow{2}{*}{0.032} & Cooking oils \\
\hline 33 & 0.027 & 0.206 & & & Cooking mixes, sprays, flower \\
\hline
\end{tabular}

Source: Nielsen Homescan data from 2002-2007. Tabulations include only those in the 52 identified Nielsen markets. 
Table 2: Median Nutritional Content (per Serving) of Product-Nutrition Cluster Groups

\begin{tabular}{|c|c|c|c|c|c|c|c|c|c|}
\hline Group & $\begin{array}{l}\text { Aggregate } \\
\text { Category }\end{array}$ & Calories & $\begin{array}{c}\text { Total } \\
\text { Fat }(\mathrm{g})\end{array}$ & $\begin{array}{l}\text { Salt } \\
(\mathrm{mg})\end{array}$ & $\begin{array}{c}\text { Sugar } \\
(\mathrm{g})\end{array}$ & $\begin{array}{l}\text { Cholest- } \\
\text { erol (g) }\end{array}$ & $\begin{array}{c}\begin{array}{c}\text { Protein } \\
(\mathrm{g})\end{array} \\
\end{array}$ & $\begin{array}{c}\text { Calories from } \\
\text { Fat }\end{array}$ & $\begin{array}{c}\text { Carbs } \\
(\mathrm{g})\end{array}$ \\
\hline 1 & Fruits \& Vegetables & 80 & 0 & 5 & 12 & 0 & 1 & 0 & 20 \\
\hline 2 & Fruits \& Vegetables & 34 & 0 & 10 & 3 & 0 & 1 & 0 & 8 \\
\hline 3 & Fruits \& Vegetables & 45 & 0 & 340 & 2 & 0 & 2 & 0 & 9 \\
\hline 4 & Cold Beverages & 0 & 0 & 2 & 0 & 0 & 0 & 0 & 0 \\
\hline 5 & Cold Beverages & 110 & 0 & 15 & 25 & 0 & 0.4 & 0 & 29 \\
\hline 6 & Cold Beverages & 110 & 0 & 96 & 22 & 0 & 0 & 0 & 26 \\
\hline 7 & Cold Beverages & 60 & 0 & 70 & 14 & 0 & 0 & 0 & 16 \\
\hline 8 & Warm Beverages & 70 & 0.5 & 0 & 12 & 0 & 0 & 5 & 15 \\
\hline 9 & Warm Beverages & 40 & 0 & 20 & 4 & 0 & 0 & 0 & 3 \\
\hline 10 & Warm Beverages & 63 & 2 & 33 & 6 & 0 & 0.1 & 16 & 9 \\
\hline 11 & Soda & 0 & 0 & 30 & 0 & 4 & 0 & 0 & 0 \\
\hline 12 & Soda & 140 & 0 & 35 & 36 & 3 & 0 & 0 & 36 \\
\hline 13 & Packaged Meals & 234 & 12 & 630 & 2 & 30 & 13 & 110 & 21 \\
\hline 14 & Packaged Meals & 270 & 8 & 616 & 4 & 25 & 13 & 72 & 33 \\
\hline 15 & Grain, Pasta, Bread & 110 & 1.5 & 230 & 2 & 0 & 4 & 15 & 22 \\
\hline 16 & Grain, Pasta, Bread & 210 & 1 & 15 & 2 & 0 & 6 & 12 & 41 \\
\hline 17 & Grain, Pasta, Bread & 136 & 2.5 & 230 & 3 & 0 & 4 & 24 & 27 \\
\hline 18 & Canned Food, Sauce & 15 & 0 & 290 & 4 & 0 & 0 & 0 & 4 \\
\hline 19 & Canned Food, Sauce & 78 & 2 & 630 & 1 & 0.5 & 2 & 17 & 11 \\
\hline 20 & Cereal, Breakfast & 156 & 1.5 & 215 & 11 & 0 & 4 & 15 & 30 \\
\hline 21 & Cereal, Breakfast & 150 & 3 & 105 & 10 & 0 & 4 & 25 & 27 \\
\hline 22 & Other Dairy & 100 & 5 & 100 & 4 & 15 & 5 & 45 & 8 \\
\hline 23 & Meat, Protein & 90 & 4.5 & 250 & 1 & 37 & 10 & 40 & 1 \\
\hline 24 & Meat, Protein & 280 & 20 & 52 & 0 & 75 & 23 & 180 & 0 \\
\hline 25 & Meat, Protein & 137 & 9 & 500 & 1 & 30 & 7 & 80 & 1.5 \\
\hline 26 & Condiments, Spices & 50 & 0 & 115 & 2 & 0 & 0 & 0 & 5 \\
\hline 27 & Condiments, Spices & 40 & 3 & 266 & 1 & 0 & 0 & 30 & 2 \\
\hline 28 & Snacks, Candy & 147 & 5 & 55 & 13 & 0 & 2 & 50 & 21 \\
\hline 29 & Snacks, Candy & 150 & 7 & 174 & 2 & 0 & 2 & 66 & 19 \\
\hline 30 & Milk & 128 & 5 & 129 & 12 & 20 & 8 & 45 & 13 \\
\hline 31 & Milk & 119 & 3.5 & 129 & 12 & 15 & 8 & 30 & 13 \\
\hline 32 & Baking Goods & 120 & 14 & 0 & 0 & 0 & 0 & 120 & 0 \\
\hline 33 & Baking Goods & 108 & 1.5 & 70 & 4 & 0 & 1 & 15 & 19 \\
\hline
\end{tabular}

Source: Nielsen Homescan data combined with Gladson and FoodEssentials food label information. Tabulations include only those in the 52 identified Nielsen markets. 
Table 3: Mean Own Price Elasticities of Demand and Expenditure Elasticities

\begin{tabular}{|c|c|c|c|c|c|}
\hline Group & $\begin{array}{l}\text { Aggregate } \\
\text { Category }\end{array}$ & $\begin{array}{l}\text { Own Price } \\
\text { Elasticity }\end{array}$ & $\begin{array}{c}\text { Standard } \\
\text { Error }\end{array}$ & $\begin{array}{c}\text { Expenditure } \\
\text { Elasticity }\end{array}$ & $\begin{array}{c}\text { Standard } \\
\text { Error }\end{array}$ \\
\hline 1 & Fruits \& Vegetables & -1.128 & 0.004 & 1.425 & 0.014 \\
\hline 2 & Fruits \& Vegetables & -0.830 & 0.004 & 1.191 & 0.015 \\
\hline 3 & Fruits \& Vegetables & -1.379 & 0.004 & 1.491 & 0.012 \\
\hline 4 & Cold Beverages & -1.835 & 0.004 & 3.096 & 0.032 \\
\hline 5 & Cold Beverages & -1.895 & 0.004 & 2.151 & 0.018 \\
\hline 6 & Cold Beverages & -1.812 & 0.004 & 1.719 & 0.012 \\
\hline 7 & Cold Beverages & -2.055 & 0.006 & 1.902 & 0.018 \\
\hline 8 & Warm Beverages & -1.521 & 0.014 & 1.210 & 0.010 \\
\hline 9 & Warm Beverages & -0.518 & 0.005 & 0.322 & 0.017 \\
\hline 10 & Warm Beverages & -0.665 & 0.010 & 0.564 & 0.017 \\
\hline 11 & Soda & -2.260 & 0.006 & 4.485 & 0.044 \\
\hline 12 & Soda & -2.197 & 0.005 & 4.122 & 0.041 \\
\hline 13 & Packaged Meals & -0.332 & 0.004 & 0.582 & 0.008 \\
\hline 14 & Packaged Meals & 0.120 & 0.005 & -0.756 & 0.018 \\
\hline 15 & Grain, Pasta, Bread & -0.845 & 0.004 & 1.363 & 0.010 \\
\hline 16 & Grain, Pasta, Bread & -0.647 & 0.006 & 0.849 & 0.013 \\
\hline 17 & Grain, Pasta, Bread & -0.292 & 0.004 & 0.716 & 0.010 \\
\hline 18 & Canned Food, Sauce & -1.083 & 0.004 & 1.158 & 0.009 \\
\hline 19 & Canned Food, Sauce & -0.907 & 0.003 & 0.953 & 0.011 \\
\hline 20 & Cereal, Breakfast & -0.244 & 0.004 & 0.883 & 0.011 \\
\hline 21 & Cereal, Breakfast & 0.022 & 0.005 & 0.135 & 0.013 \\
\hline 22 & Other Dairy & -0.731 & 0.003 & 0.728 & 0.008 \\
\hline 23 & Meat, Protein & 0.011 & 0.005 & 0.155 & 0.015 \\
\hline 24 & Meat, Protein & -0.696 & 0.005 & 0.846 & 0.006 \\
\hline 25 & Meat, Protein & -0.253 & 0.004 & 0.692 & 0.011 \\
\hline 26 & Condiments, Spices & -0.431 & 0.002 & 0.269 & 0.013 \\
\hline 27 & Condiments, Spices & -0.669 & 0.002 & 0.877 & 0.010 \\
\hline 28 & Snacks, Candy & -0.270 & 0.004 & -0.876 & 0.015 \\
\hline 29 & Snacks, Candy & -0.295 & 0.004 & 0.404 & 0.009 \\
\hline 30 & Milk & -1.793 & 0.003 & 2.296 & 0.015 \\
\hline 31 & Milk & -1.972 & 0.004 & 1.693 & 0.017 \\
\hline 32 & Baking Goods & -1.631 & 0.004 & 1.253 & 0.006 \\
\hline 33 & Baking Goods & -0.575 & 0.003 & 0.634 & 0.012 \\
\hline
\end{tabular}

Source: Authors' calculations from 2002-2007 Nielsen Homescan data. The sample includes only consumers in the 52 identified Nielsen markets. The table shows average elasticities of demand and standard errors that are calculated from the QUAIDS model parameter estimates. 


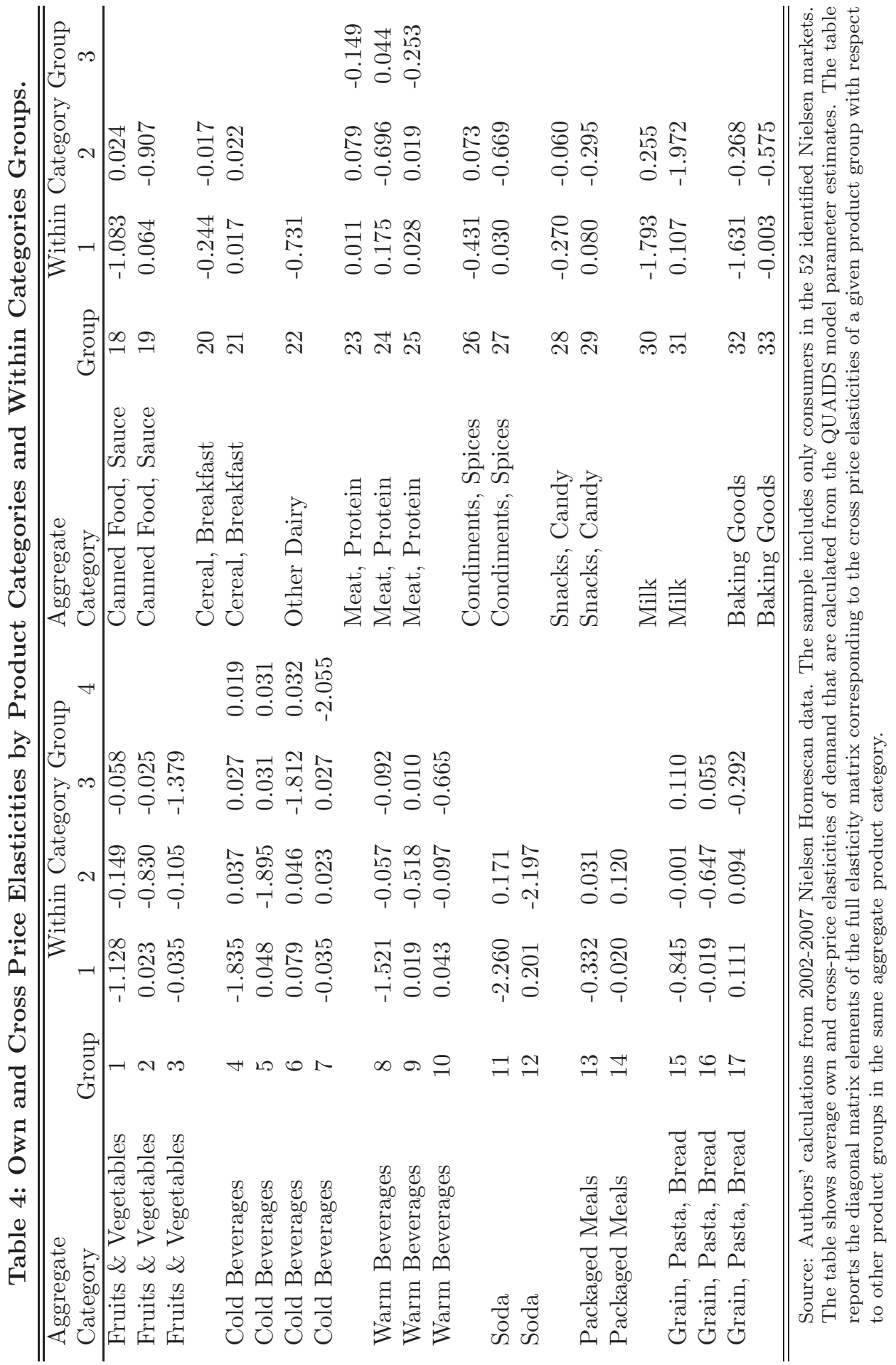


Table 5: Tax Simulations - Product Taxes on Soda and Sugar-Sweetened Beverages

\begin{tabular}{|c|c|c|c|c|c|c|c|c|c|c|c|}
\hline \multirow[b]{2}{*}{ Category } & \multicolumn{11}{|c|}{ Panel A: 20\% Soda Tax (Indirect Utility Cost $=2.5 \% ; \mathrm{EV}=\$ 21.22$ ) } \\
\hline & $\begin{array}{c}\% \Delta \\
\text { Expend. }\end{array}$ & $\begin{array}{l}\% \Delta \\
\text { Share }\end{array}$ & $\begin{array}{l}\% \Delta \\
\text { Price }\end{array}$ & Calories & $\begin{array}{l}\text { Calories } \\
\text { from Fat }\end{array}$ & $\begin{array}{c}\text { Total } \\
\text { Fat }\end{array}$ & $\begin{array}{l}\text { Carbo- } \\
\text { hydrates }\end{array}$ & Sugar & $\begin{array}{l}\text { Pro- } \\
\text { tein }\end{array}$ & $\begin{array}{l}\text { Chole- } \\
\text { sterol }\end{array}$ & Salt \\
\hline Fruits \& Vegetables & -1.15 & 1.13 & 0.00 & -41.6 & 0.0 & 0.0 & -9.4 & -4.3 & -0.8 & 0.0 & -10.2 \\
\hline Cold Beverages & -0.72 & 0.95 & 0.00 & -38.4 & 0.0 & 0.0 & -11.2 & -9.5 & -0.1 & 0.0 & -29.9 \\
\hline Warm Beverages & -1.69 & -1.47 & 0.00 & -270.5 & -53.6 & -3.2 & -36.5 & -25.9 & -0.3 & 0.0 & -29.2 \\
\hline Soda & -3.92 & -3.43 & 20.00 & -2231.1 & 0.0 & 0.0 & -634.6 & -674.7 & 0.0 & -66.5 & -869.3 \\
\hline Packaged Meals & -2.98 & -1.84 & 0.00 & -180.3 & -66.9 & -7.3 & -17.6 & -3.0 & -9.2 & -22.4 & -472.0 \\
\hline Grain, Pasta, Bread & -1.09 & 0.81 & 0.00 & -154.4 & -27.2 & -2.9 & -28.4 & -3.6 & -4.7 & 0.0 & -331.0 \\
\hline Canned Food, Sauce & -1.02 & -0.15 & 0.00 & -28.7 & -3.3 & -0.4 & -5.3 & -2.1 & -0.6 & -0.2 & -336.7 \\
\hline Cereal, Breakfast & -2.92 & -1.36 & 0.00 & -330.9 & -37.6 & -4.1 & -64.0 & -20.5 & -7.5 & 0.0 & -399.4 \\
\hline Other Dairy & -0.94 & 0.53 & 0.00 & -76.0 & -35.7 & -4.0 & -5.0 & -3.3 & -2.5 & -7.4 & -59.1 \\
\hline Meat, Protein & -1.36 & -1.39 & 0.00 & -902.7 & -3019.4 & -335.7 & -3.4 & -1.6 & -94.3 & -301.6 & -896.4 \\
\hline Condiments, Spices & -0.99 & 0.48 & 0.00 & -43.8 & -15.4 & -1.7 & -3.1 & -1.5 & 0.0 & 0.0 & -179.6 \\
\hline Snacks, Candy & -0.88 & 0.89 & 0.00 & -92.3 & -34.9 & -3.9 & -11.9 & -2.5 & -1.5 & 0.0 & -93.5 \\
\hline Milk & -0.26 & 1.41 & 0.00 & -12.4 & -2.7 & -0.3 & -1.5 & -1.1 & -0.9 & -1.6 & -11.9 \\
\hline Baking Goods & -1.61 & 0.24 & 0.00 & -376.6 & -213.2 & -24.4 & -29.3 & -10.1 & -1.2 & 0.0 & -81.3 \\
\hline Total & -1.66 & & & -4779.8 & -3510.0 & -387.9 & -861.3 & -763.6 & -123.6 & -399.7 & -3799.5 \\
\hline Percent & & & & -4.84 & -7.37 & -7.31 & -5.67 & -10.35 & -3.70 & -3.54 & -2.03 \\
\hline \multirow[b]{2}{*}{ Category } & \multicolumn{11}{|c|}{ Panel B: 20\% Tax on SSBs (Indirect Utility Cost $=2.0 \% ; \mathrm{EV}=\$ 20.05$ ) } \\
\hline & $\begin{array}{c}\% \Delta \\
\text { Expend. }\end{array}$ & $\begin{array}{l}\% \Delta \\
\text { Share }\end{array}$ & $\begin{array}{l}\% \Delta \\
\text { Price }\end{array}$ & Calories & $\begin{array}{l}\text { Calories } \\
\text { from Fat }\end{array}$ & $\begin{array}{c}\text { Total } \\
\text { Fat }\end{array}$ & $\begin{array}{c}\text { Carbo- } \\
\text { hydrates }\end{array}$ & Sugar & $\begin{array}{l}\text { Pro- } \\
\text { tein }\end{array}$ & $\begin{array}{l}\text { Chole- } \\
\text { sterol }\end{array}$ & Salt \\
\hline Fruits \& Vegetables & -0.49 & 0.92 & 0.00 & -17.6 & 0.0 & 0.0 & -4.0 & -1.9 & -0.3 & 0.0 & -1.4 \\
\hline Cold Beverages & -0.76 & 0.03 & 14.90 & -1602.3 & 0.0 & 0.0 & -422.7 & -368.5 & -2.6 & 0.0 & -1224.6 \\
\hline Warm Beverages & -0.57 & -1.22 & 20.00 & -3258.5 & -652.9 & -40.1 & -442.4 & -313.2 & -4.1 & 0.0 & -365.0 \\
\hline Soda & -7.26 & -7.60 & 8.34 & -2832.2 & 0.0 & 0.0 & -797.5 & -750.5 & 0.0 & -73.3 & -790.7 \\
\hline Packaged Meals & -0.62 & -0.33 & 0.00 & -39.8 & -15.1 & -1.7 & -3.8 & -0.6 & -2.0 & -5.0 & -104.9 \\
\hline Grain, Pasta, Bread & -0.33 & 0.71 & 0.00 & -44.4 & -8.0 & -0.9 & -8.2 & -1.1 & -1.4 & 0.0 & -105.0 \\
\hline Canned Food, Sauce & -0.36 & -0.36 & 0.00 & -10.7 & -1.1 & -0.1 & -2.0 & -0.9 & -0.2 & -0.1 & -131.4 \\
\hline Cereal, Breakfast & -0.70 & 0.02 & 0.00 & -78.6 & -8.6 & -0.9 & -15.2 & -4.9 & -1.8 & 0.0 & -97.6 \\
\hline Other Dairy & -0.23 & 0.37 & 0.00 & -18.8 & -8.8 & -1.0 & -1.2 & -0.8 & -0.6 & -1.8 & -14.6 \\
\hline Meat, Protein & -0.28 & 0.11 & 0.00 & -239.6 & -845.6 & -94.0 & -0.8 & -0.4 & -25.4 & -81.5 & -212.9 \\
\hline Condiments, Spices & -0.21 & 0.39 & 0.00 & -10.1 & -4.3 & -0.5 & -0.6 & -0.3 & 0.0 & 0.0 & -45.7 \\
\hline Snacks, Candy & -0.13 & 0.76 & 0.00 & -16.4 & -6.4 & -0.7 & -2.1 & -0.4 & -0.3 & 0.0 & -17.5 \\
\hline Milk & -0.06 & 0.72 & 0.00 & 6.6 & 2.9 & 0.3 & 0.6 & 0.8 & 0.4 & 1.1 & 8.4 \\
\hline Baking Goods & -0.51 & 0.47 & 0.00 & -174.5 & -121.5 & -14.0 & -8.4 & -2.9 & -0.3 & 0.0 & -23.2 \\
\hline Total & -1.66 & & & -8337.0 & -1669.3 & -153.4 & -1708.2 & -1445.4 & -38.7 & -160.6 & -3126.2 \\
\hline Percent & & & & -8.44 & -3.50 & -2.89 & -11.25 & -19.59 & -1.16 & -1.42 & -1.67 \\
\hline
\end{tabular}

Source: Nielsen Homescan data. Indirect utility costs are calculated using equation (1). We calculate V for each household under the old a new price regimes; percent change in average indirect utility over all households and time periods are shown. EV is the equivalent variation total expenditure that would generate the same decline in indirect utility. 
Table 6: Tax Simulations - Product Taxes on Packaged Meals and Snacks

\begin{tabular}{|c|c|c|c|c|c|c|c|c|c|c|c|}
\hline \multirow[b]{2}{*}{ Category } & \multicolumn{11}{|c|}{ " Panel A: 20\% Packaged Meal Tax (Indirect Utility Cost $=1.4 \% ; \mathrm{EV}=\$ 13.23$ ) } \\
\hline & $\begin{array}{c}\% \Delta \\
\text { Expend. }\end{array}$ & $\begin{array}{l}\% \Delta \\
\text { Share }\end{array}$ & $\begin{array}{l}\% \Delta \\
\text { Price }\end{array}$ & Calories & $\begin{array}{l}\text { Calories } \\
\text { from Fat }\end{array}$ & $\begin{array}{c}\text { Total } \\
\text { Fat }\end{array}$ & $\begin{array}{l}\text { Carbo- } \\
\text { hydrates }\end{array}$ & Sugar & $\begin{array}{l}\text { Pro- } \\
\text { tein }\end{array}$ & $\begin{array}{l}\text { Chole- } \\
\text { sterol }\end{array}$ & Salt \\
\hline Fruits \& Vegetables & 3.61 & 2.51 & 0.00 & 171.6 & 0.0 & 0.0 & 38.1 & 15.8 & 3.7 & 0.0 & 412.0 \\
\hline Cold Beverages & 1.61 & -0.09 & 0.00 & 122.8 & 0.0 & 0.0 & 34.2 & 29.2 & 0.2 & 0.0 & 98.8 \\
\hline Warm Beverages & 0.56 & -2.54 & 0.00 & 214.1 & 40.0 & 1.8 & 28.2 & 18.7 & 0.1 & 0.0 & 10.3 \\
\hline Soda & 2.74 & -0.14 & 0.00 & 212.2 & 0.0 & 0.0 & 60.6 & 66.9 & 0.0 & 6.6 & 90.8 \\
\hline Packaged Meals & 7.96 & 5.62 & 20.00 & -897.8 & -347.6 & -38.0 & -82.3 & -13.4 & -45.1 & -113.1 & -2381.7 \\
\hline Grain, Pasta, Bread & 1.87 & 0.41 & 0.00 & 363.9 & 48.0 & 5.1 & 66.3 & 7.3 & 10.3 & 0.0 & 430.3 \\
\hline Canned Food, Sauce & 0.25 & -2.21 & 0.00 & 10.9 & 0.4 & 0.0 & 2.2 & 1.2 & 0.1 & 0.0 & 155.7 \\
\hline Cereal, Breakfast & 2.10 & 0.32 & 0.00 & 220.2 & 26.5 & 2.9 & 42.3 & 13.4 & 5.0 & 0.0 & 252.5 \\
\hline Other Dairy & -0.42 & -2.27 & 0.00 & -33.7 & -15.9 & -1.8 & -2.2 & -1.5 & -1.1 & -3.3 & -26.2 \\
\hline Meat, Protein & 0.76 & -0.46 & 0.00 & 308.4 & 1058.6 & 117.7 & 1.1 & 0.5 & 33.6 & 105.4 & 248.3 \\
\hline Condiments, Spices & -0.62 & -2.47 & 0.00 & -17.9 & 4.4 & 0.5 & -2.7 & -1.1 & 0.0 & 0.0 & -8.9 \\
\hline Snacks, Candy & -0.11 & -1.68 & 0.00 & -37.0 & -15.7 & -1.8 & -4.5 & -0.2 & -0.7 & 0.0 & -46.4 \\
\hline Milk & 2.38 & 0.66 & 0.00 & 222.3 & 65.5 & 7.3 & 25.1 & 22.6 & 14.9 & 30.4 & 237.8 \\
\hline Baking Goods & 1.80 & 0.29 & 0.00 & 1220.7 & 1022.3 & 118.3 & 18.8 & 6.5 & 0.8 & 0.0 & 52.2 \\
\hline Total & 1.70 & & & 2080.5 & 1886.5 & 212.2 & 225.1 & 166.0 & 21.9 & 26.0 & -474.4 \\
\hline Percent & & & & 2.11 & 3.96 & 4.00 & 1.48 & 2.25 & 0.65 & 0.23 & -0.25 \\
\hline & \multicolumn{11}{|c|}{ Panel B: 20\% Snack, Candy Tax (Indirect Utility Cost $=2.0 \% ; \mathrm{EV}=\$ 20.04$ ) } \\
\hline Category & $\begin{array}{c}\% \Delta \\
\text { Expend. }\end{array}$ & $\begin{array}{c}\% \Delta \\
\text { Share }\end{array}$ & $\begin{array}{l}\% \Delta \\
\text { Price }\end{array}$ & $\begin{array}{l}\text { Calories } \\
\text { Calories }\end{array}$ & $\begin{array}{c}\text { Total } \\
\text { from Fat }\end{array}$ & Fat & $\begin{array}{l}\text { Carbo- } \\
\text { hydrates }\end{array}$ & Sugar & $\begin{array}{l}\text { Pro- } \\
\text { tein }\end{array}$ & $\begin{array}{l}\text { Chole- } \\
\text { sterol }\end{array}$ & Salt \\
\hline Fruits \& Vegetables & 0.79 & 0.67 & 0.00 & 69.9 & 0.0 & 0.0 & 16.0 & 7.0 & 1.2 & 0.0 & 177.9 \\
\hline Cold Beverages & 1.00 & 0.25 & 0.00 & 68.4 & 0.0 & 0.0 & 18.7 & 16.2 & 0.2 & 0.0 & 34.2 \\
\hline Warm Beverages & 0.41 & -1.76 & 0.00 & 278.2 & 51.5 & 2.2 & 36.5 & 23.7 & 0.1 & 0.0 & 9.6 \\
\hline Soda & 0.34 & -1.55 & 0.00 & 7.7 & 0.0 & 0.0 & 2.4 & 4.3 & 0.0 & 0.4 & 8.8 \\
\hline Packaged Meals & -0.28 & -1.52 & 0.00 & 22.7 & 12.2 & 1.3 & 0.9 & 0.0 & 1.0 & 3.3 & 67.7 \\
\hline Grain, Pasta, Bread & -0.24 & -0.73 & 0.00 & -11.6 & -5.3 & -0.6 & -2.4 & -0.6 & -0.6 & 0.0 & -110.8 \\
\hline Canned Food, Sauce & 0.37 & -1.16 & 0.00 & 10.3 & 1.2 & 0.1 & 1.9 & 0.7 & 0.2 & 0.1 & 120.5 \\
\hline Cereal, Breakfast & 0.39 & -0.42 & 0.00 & 42.8 & 4.8 & 0.5 & 8.3 & 2.7 & 1.0 & 0.0 & 52.0 \\
\hline Other Dairy & -1.00 & -1.92 & 0.00 & -81.0 & -38.1 & -4.2 & -5.4 & -3.5 & -2.7 & -7.9 & -63.0 \\
\hline Meat, Protein & -0.95 & -1.31 & 0.00 & 115.2 & 789.3 & 87.7 & -1.1 & -0.4 & 14.6 & 50.1 & -73.2 \\
\hline Condiments, Spices & -0.64 & -1.56 & 0.00 & -23.2 & -2.5 & -0.3 & -2.4 & -1.1 & 0.0 & 0.0 & -61.1 \\
\hline Snacks, Candy & 4.71 & 4.04 & 20.00 & -2149.3 & -847.0 & -94.7 & -271.6 & -42.9 & -35.8 & -0.2 & -2359.1 \\
\hline Milk & 1.28 & 0.52 & 0.00 & 104.3 & 29.5 & 3.3 & 11.9 & 10.4 & 7.0 & 14.1 & 109.8 \\
\hline Baking Goods & 0.11 & -0.44 & 0.00 & 351.0 & 330.6 & 38.4 & -3.0 & -1.0 & -0.1 & 0.0 & -8.4 \\
\hline Total & 0.74 & & & -1194.5 & 326.3 & 33.6 & -189.5 & 15.6 & -14.0 & 60.0 & -2095.1 \\
\hline Percent & & & & -1.21 & 0.68 & 0.63 & -1.25 & 0.21 & -0.42 & 0.53 & -1.12 \\
\hline
\end{tabular}

Source: Nielsen Homescan data. Indirect utility costs are calculated using equation (1). We calculate V for each household under the old a new price regimes; percent change in average indirect utility over all households and time periods are shown. EV is the equivalent variation total expenditure that would generate the same decline in indirect utility. 
Table 7: Tax Simulations - Nutrient Specific Taxes

\begin{tabular}{|c|c|c|c|c|c|c|c|c|c|c|c|}
\hline \multirow[b]{2}{*}{ Category } & \multicolumn{11}{|c|}{ Panel A: 20\% Fat Tax (Indirect Utility Cost $=2.0 \% ; \mathrm{EV}=\$ 20.04$ ) } \\
\hline & $\begin{array}{c}\% \Delta \\
\text { Expend. }\end{array}$ & $\begin{array}{l}\% \Delta \\
\text { Share }\end{array}$ & $\begin{array}{l}\% \Delta \\
\text { Price }\end{array}$ & Calories & $\begin{array}{l}\text { Calories } \\
\text { from Fat }\end{array}$ & $\begin{array}{l}\text { Total } \\
\text { Fat }\end{array}$ & $\begin{array}{l}\text { Carbo- } \\
\text { hydrates }\end{array}$ & Sugar & $\begin{array}{l}\text { Pro- } \\
\text { tein }\end{array}$ & $\begin{array}{l}\text { Chole- } \\
\text { sterol }\end{array}$ & Salt \\
\hline Fruits \& Vegetables & -0.70 & -0.29 & 8.37 & -284.9 & 0.0 & 0.0 & -61.1 & -24.4 & -7.4 & 0.0 & -521.9 \\
\hline Cold Beverages & 1.76 & 1.56 & 0.10 & 132.5 & 0.0 & 0.0 & 36.7 & 31.4 & 0.2 & 0.0 & 117.9 \\
\hline Warm Beverages & 0.34 & -1.30 & 4.90 & -1921.4 & -382.4 & -20.9 & -260.2 & -173.4 & -1.8 & 0.0 & -138.6 \\
\hline Soda & 3.16 & 1.77 & 0.00 & 207.7 & 0.0 & 0.0 & 59.5 & 69.0 & 0.0 & 6.8 & 99.2 \\
\hline Packaged Meals & -0.23 & -0.93 & 6.59 & -581.3 & -233.0 & -25.4 & -50.5 & -7.9 & -28.8 & -74.2 & -1559.4 \\
\hline Grain, Pasta, Bread & 0.00 & 0.04 & 12.14 & -2061.9 & -308.3 & -32.9 & -378.2 & -44.1 & -60.7 & 0.0 & -3315.2 \\
\hline Canned Food, Sauce & 0.37 & -0.63 & 2.79 & -68.2 & -7.7 & -0.8 & -12.7 & -5.0 & -1.3 & -0.5 & -805.4 \\
\hline Cereal, Breakfast & -0.03 & -0.29 & 6.72 & -723.0 & -87.4 & -9.6 & -138.9 & -44.0 & -16.5 & 0.0 & -826.4 \\
\hline Other Dairy & -0.67 & -1.06 & 18.76 & -1561.6 & -734.0 & -81.5 & -103.1 & -67.2 & -52.4 & -152.3 & -1214.0 \\
\hline Meat, Protein & -0.35 & -0.45 & 16.07 & -2903.5 & -6691.1 & -744.5 & -21.4 & -10.3 & -266.5 & -860.5 & -4940.0 \\
\hline Condiments, Spices & 0.56 & 0.17 & 14.93 & -648.8 & -248.8 & -27.6 & -43.3 & -21.9 & 0.0 & 0.0 & -2788.5 \\
\hline Snacks, Candy & -0.06 & -0.16 & 11.77 & -2375.8 & -972.2 & -108.9 & -294.3 & -30.8 & -40.7 & -0.1 & -2800.2 \\
\hline Milk & 0.42 & 0.20 & 11.91 & -1046.8 & -304.2 & -33.9 & -118.6 & -105.8 & -70.5 & -142.7 & -1114.0 \\
\hline Baking Goods & 1.74 & 1.73 & 7.10 & -5147.6 & -4487.8 & -519.8 & -38.6 & -13.3 & -1.6 & 0.0 & -107.0 \\
\hline Total & 0.20 & & & -18984.4 & -14456.9 & -1605.9 & -1424.5 & -447.6 & -548.0 & -1223.5 & -19913.5 \\
\hline Percent & & & & -19.23 & -30.35 & -30.25 & -9.38 & -6.07 & -16.38 & -10.83 & -10.63 \\
\hline \multirow[b]{2}{*}{ Category } & \multicolumn{11}{|c|}{ Panel B: 20\% Sugar Tax (Indirect Utility Cost $=2.6 \% ; \mathrm{EV}=\$ 21.37$ ) } \\
\hline & $\begin{array}{c}\% \Delta \\
\text { Expend. }\end{array}$ & $\begin{array}{l}\% \Delta \\
\text { Share }\end{array}$ & $\begin{array}{l}\% \Delta \\
\text { Price }\end{array}$ & Calories & $\begin{array}{l}\text { Calories } \\
\text { from Fat }\end{array}$ & $\begin{array}{c}\text { Total } \\
\text { Fat }\end{array}$ & $\begin{array}{c}\text { Carbo- } \\
\text { hydrates }\end{array}$ & Sugar & $\begin{array}{l}\text { Pro- } \\
\text { tein }\end{array}$ & $\begin{array}{l}\text { Chole- } \\
\text { sterol }\end{array}$ & Salt \\
\hline Fruits \& Vegetables & -2.53 & -2.55 & 7.84 & -745.7 & 0.0 & 0.0 & -174.1 & -82.2 & -10.9 & 0.0 & -864.2 \\
\hline Cold Beverages & 6.44 & 5.75 & 14.06 & -1326.3 & 0.0 & 0.0 & -349.5 & -302.6 & -1.5 & 0.0 & -1319.5 \\
\hline Warm Beverages & 1.24 & -0.86 & 13.90 & -2041.9 & -462.7 & -35.9 & -294.2 & -209.8 & -4.4 & 0.0 & -339.8 \\
\hline Soda & 11.52 & 9.53 & 14.16 & -606.2 & 0.0 & 0.0 & -170.8 & -162.0 & 0.0 & -15.8 & -173.2 \\
\hline Packaged Meals & -0.81 & -1.94 & 1.84 & -135.3 & -48.2 & -5.3 & -13.9 & -2.4 & -7.0 & -16.5 & -349.9 \\
\hline Grain, Pasta, Bread & 0.00 & -0.40 & 7.98 & -1479.5 & -206.1 & -21.9 & -269.4 & -30.1 & -42.1 & 0.0 & -1910.4 \\
\hline Canned Food, Sauce & 1.34 & -0.11 & 5.84 & -220.2 & -5.7 & -0.6 & -45.5 & -25.8 & -1.0 & -0.4 & -3248.8 \\
\hline Cereal, Breakfast & -0.09 & -0.80 & 15.76 & -1749.8 & -196.1 & -21.3 & -338.7 & -108.5 & -39.9 & 0.0 & -2133.1 \\
\hline Other Dairy & -2.43 & -3.24 & 5.24 & -620.4 & -291.6 & -32.4 & -41.0 & -26.7 & -20.8 & -60.5 & -482.3 \\
\hline Meat, Protein & -1.25 & -1.71 & 5.00 & -317.8 & 936.4 & 103.7 & -8.6 & -3.7 & -18.5 & -45.8 & -1321.9 \\
\hline Condiments, Spices & 2.05 & 1.20 & 12.63 & -426.2 & -106.6 & -11.8 & -36.1 & -16.8 & 0.0 & 0.0 & -1488.1 \\
\hline Snacks, Candy & -0.86 & -1.40 & 10.47 & -1979.3 & -800.2 & -89.6 & -246.8 & -30.2 & -33.6 & -0.1 & -2280.3 \\
\hline Milk & 1.52 & 0.86 & 20.29 & -1748.4 & -511.0 & -57.0 & -197.7 & -177.2 & -117.6 & -238.8 & -1865.0 \\
\hline Baking Goods & 6.57 & 6.09 & 13.18 & -4905.4 & -4018.5 & -464.9 & -96.2 & -33.2 & -4.0 & 0.0 & -266.7 \\
\hline Total & 0.64 & & & -18302.4 & -5710.3 & -636.9 & -2282.5 & -1211.1 & -301.2 & -378.0 & -18043.3 \\
\hline Percent & & & & -18.54 & -11.99 & -12.00 & -15.03 & -16.41 & -9.00 & -3.34 & -9.63 \\
\hline \multirow[b]{2}{*}{ Category } & \multicolumn{11}{|c|}{ Panel C: $20 \%$ Salt Tax (Indirect Utility Cost $=1.2 \% ; \mathrm{EV}=\$ 10.95$ ) } \\
\hline & $\begin{array}{c}\% \Delta \\
\text { Expend. }\end{array}$ & $\begin{array}{l}\% \Delta \\
\text { Share }\end{array}$ & $\begin{array}{l}\% \Delta \\
\text { Price }\end{array}$ & Calories & $\begin{array}{l}\text { Calories } \\
\text { from Fat }\end{array}$ & $\begin{array}{l}\text { Total } \\
\text { Fat }\end{array}$ & $\begin{array}{c}\text { Carbo- } \\
\text { hydrates }\end{array}$ & Sugar & $\begin{array}{l}\text { Pro- } \\
\text { tein }\end{array}$ & $\begin{array}{l}\text { Chole- } \\
\text { sterol }\end{array}$ & Salt \\
\hline Fruits \& Vegetables & -1.83 & -1.67 & 3.64 & -294.5 & 0.0 & 0.0 & -61.2 & -18.4 & -9.4 & 0.0 & -1714.0 \\
\hline Cold Beverages & 4.63 & 4.15 & 1.60 & 121.3 & 0.0 & 0.0 & 35.7 & 30.3 & 0.3 & 0.0 & 47.2 \\
\hline Warm Beverages & 0.89 & -1.02 & 1.75 & 3.9 & -15.8 & -3.6 & -4.7 & -5.2 & -0.6 & 0.0 & -43.1 \\
\hline Soda & 8.29 & 6.55 & 1.19 & 400.2 & 0.0 & 0.0 & 115.1 & 137.3 & 0.0 & 13.6 & 204.0 \\
\hline Packaged Meals & -0.58 & -1.54 & 6.64 & -568.7 & -224.9 & -24.5 & -50.5 & -8.0 & -28.4 & -72.2 & -1518.9 \\
\hline Grain, Pasta, Bread & -0.01 & -0.23 & 6.16 & -1186.7 & -160.2 & -17.0 & -214.0 & -23.1 & -32.6 & 0.0 & -1229.8 \\
\hline Canned Food, Sauce & 0.96 & -0.30 & 13.87 & -379.4 & -39.7 & -4.2 & -71.2 & -29.4 & -6.7 & -2.8 & -4591.1 \\
\hline Cereal, Breakfast & -0.07 & -0.59 & 9.69 & -1102.0 & -116.3 & -12.5 & -214.5 & -69.3 & -25.0 & 0.0 & -1405.7 \\
\hline Other Dairy & -1.75 & -2.39 & 5.85 & -613.2 & -288.2 & -32.0 & -40.5 & -26.4 & -20.6 & -59.8 & -476.7 \\
\hline Meat, Protein & -0.90 & -1.21 & 8.70 & -1002.8 & -164.0 & -19.0 & -14.4 & -7.2 & -61.3 & -213.6 & -3331.0 \\
\hline Condiments, Spices & 1.48 & 0.82 & 9.56 & -405.3 & -197.1 & -21.9 & -21.4 & -11.9 & 0.0 & 0.0 & -1994.7 \\
\hline Snacks, Candy & -0.62 & -0.98 & 7.17 & -1755.8 & -724.7 & -81.2 & -216.5 & -19.9 & -30.3 & 0.0 & -2102.6 \\
\hline Milk & 1.09 & 0.62 & 7.12 & -562.6 & -164.5 & -18.3 & -63.6 & -57.0 & -37.8 & -76.9 & -600.2 \\
\hline Baking Goods 4.66 & 4.38 & 6.77 & -3149.9 & -2793.2 & -323.7 & -12.8 & -4.4 & -0.5 & 0.0 & -35.5 & \\
\hline Total & 0.46 & & & -10495.5 & -4888.7 & -558.0 & -834.5 & -112.7 & -252.9 & -411.7 & -18792.1 \\
\hline Percent & & & & -10.63 & -10.26 & -10.51 & -5.49 & -1.53 & -7.56 & -3.64 & -10.03 \\
\hline
\end{tabular}
new price regimes; percent change in average indirect utility, gver all households and time periods are shown. EV is the equivalent variation total expenditure that would generate the same decline in inctirect utility. 


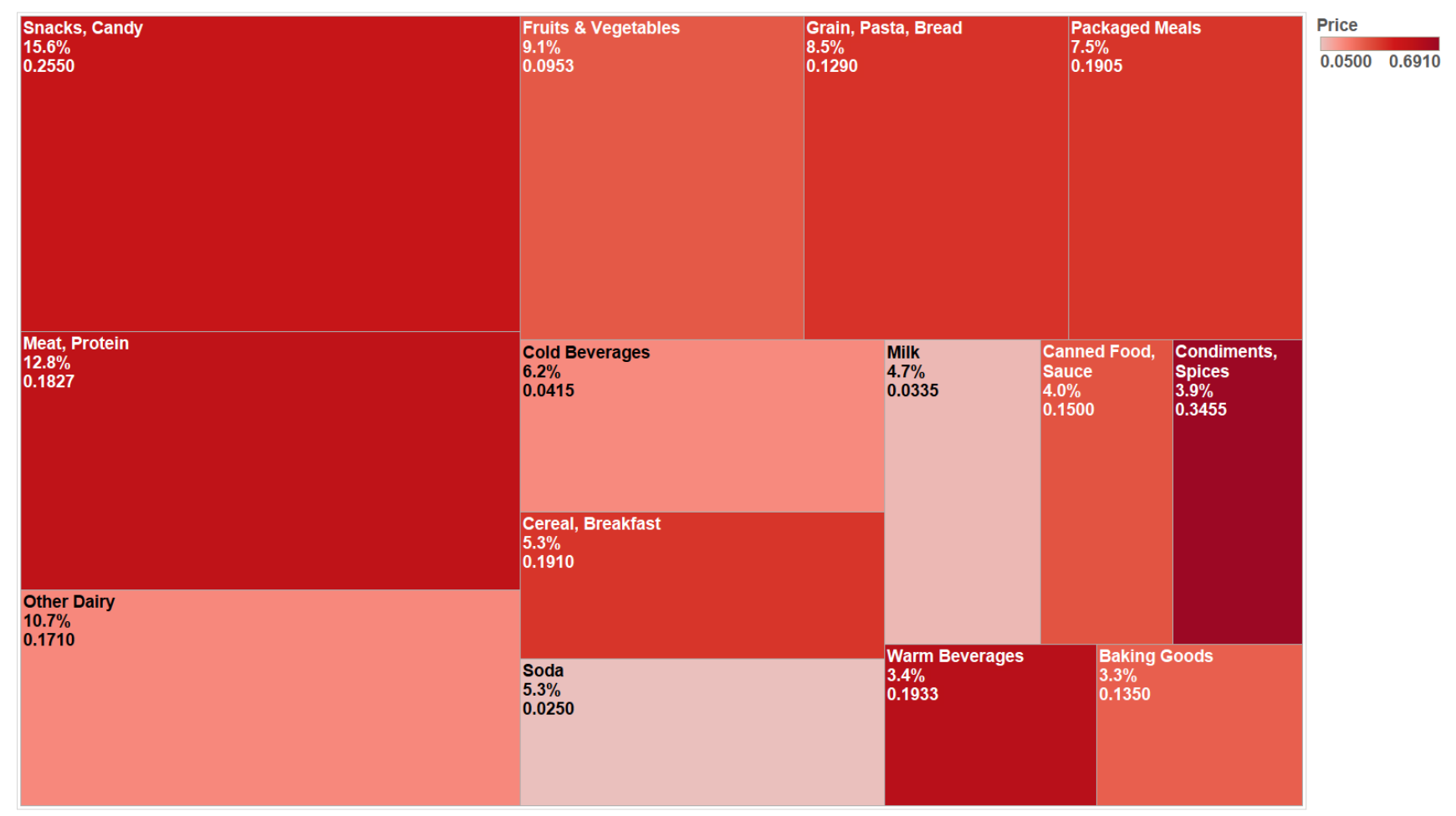

Figure 1: Graphical representation of food expenditures on the 14 major product categories in the sample. The size of the squares is proportional to the budget share of the corresponding product. The budget share is given in $\%$ under each product category name. The color shading of each rectangle corresponds to the average price per ounce of products in each of the categories. The average price per ounce (in dollars) is also reported under the budget share for each category. 


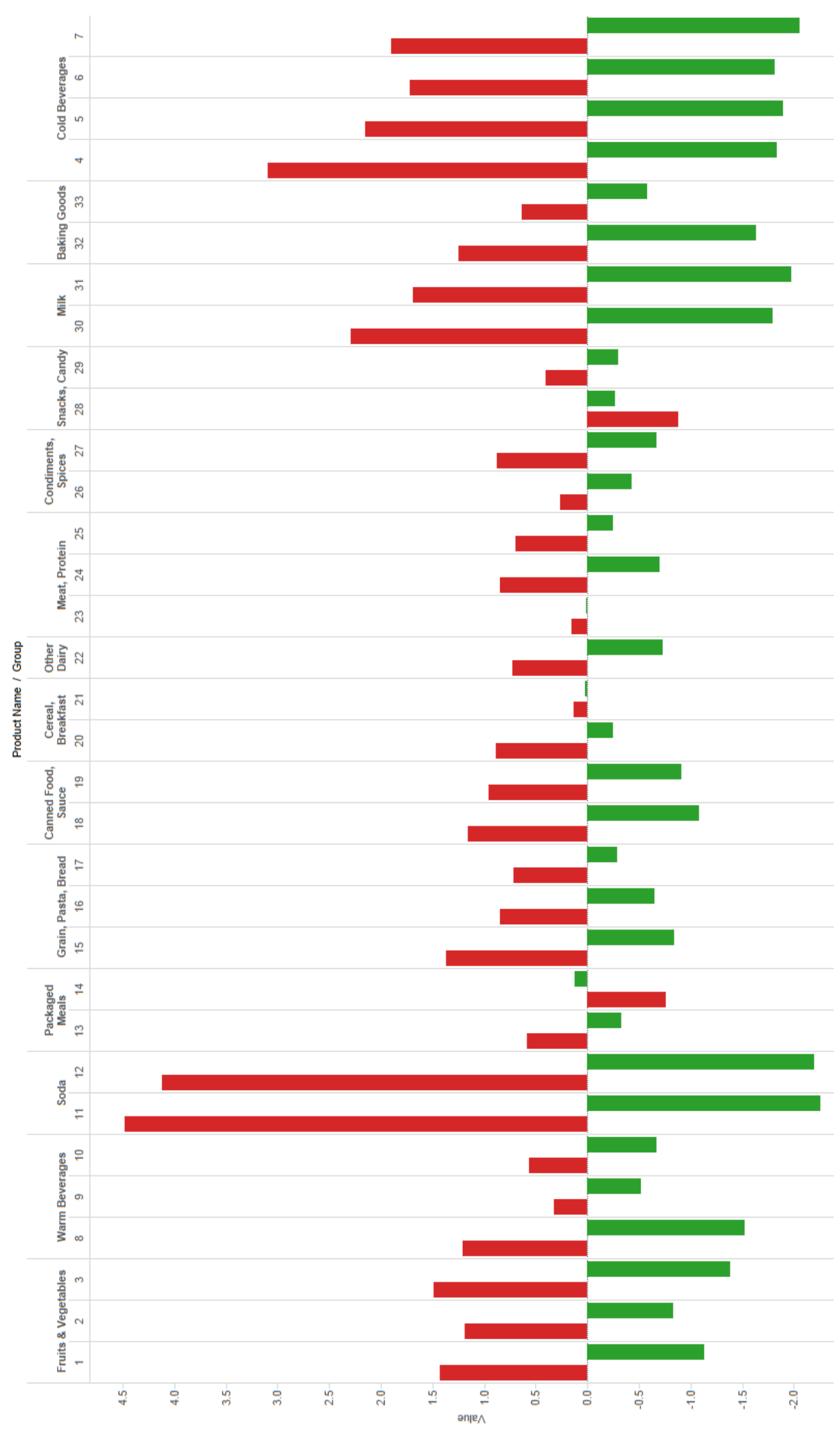

Figure 2: Own Price and Expenditure Elasticities by Product Groups and Aggregate Categories. For each group we report both elasticities. The top bar in each group corresponds to the own price elasticity. 